IZA DP No. 9098

Norwegian Rhapsody?

The Political Economy Benefits of Regional Integration

Nauro F. Campos

Fabrizio Coricelli

Luigi Moretti

June 2015 


\title{
Norwegian Rhapsody? The Political Economy Benefits of Regional Integration
}

\author{
Nauro F. Campos \\ Brunel University, ETH Zurich and IZA
}

Fabrizio Coricelli

Paris School of Economics and CEPR

Luigi Moretti

University of Padova

Discussion Paper No. 9098
June 2015

\author{
IZA \\ P.O. Box 7240 \\ 53072 Bonn \\ Germany
}

Phone: +49-228-3894-0

Fax: +49-228-3894-180

E-mail: iza@iza.org

Any opinions expressed here are those of the author(s) and not those of IZA. Research published in this series may include views on policy, but the institute itself takes no institutional policy positions. The IZA research network is committed to the IZA Guiding Principles of Research Integrity.

The Institute for the Study of Labor (IZA) in Bonn is a local and virtual international research center and a place of communication between science, politics and business. IZA is an independent nonprofit organization supported by Deutsche Post Foundation. The center is associated with the University of Bonn and offers a stimulating research environment through its international network, workshops and conferences, data service, project support, research visits and doctoral program. IZA engages in (i) original and internationally competitive research in all fields of labor economics, (ii) development of policy concepts, and (iii) dissemination of research results and concepts to the interested public.

IZA Discussion Papers often represent preliminary work and are circulated to encourage discussion. Citation of such a paper should account for its provisional character. A revised version may be available directly from the author. 


\section{ABSTRACT \\ Norwegian Rhapsody? \\ The Political Economy Benefits of Regional Integration*}

This paper investigates whether joint economic and political integration leads to larger economic benefits than just economic integration. The identification strategy rests on the fact that Norway, at the time of the 1995 Enlargement of the European Union (EU), had successfully completed negotiations and fulfilled all accession requirements, taken membership in the European Economic Area (with full access to the Single Market), but decided in a referendum to reject full-fledged EU membership. Using the differences-indifferences and synthetic control methods with regional data, we find substantial politically driven economic benefits from EU membership: if Norway had joined the EU in 1995, productivity levels between 1995 and 2001 would have been 6\% higher on average.

JEL Classification: $\quad$ C33, F15, F43, O52

Keywords: political economy benefits, European Union, labor productivity, synthetic counterfactual method, regional data

Corresponding author:

Nauro F. Campos

Department of Economics

Brunel University

Uxbridge UB8 3PH

United Kingdom

E-mail: nauro.campos@brunel.ac.uk

\footnotetext{
*We would like to thank Malin Arve, Richard Baldwin, Thomas Bassetti, Seppo Honkapohja, likka Korhonen, Mathilde Maurel, André Sapir, Stéphane Straub, Matti Viren and seminar participants at the 2015 Royal Economic Society (Manchester), U. Paris I Panthéon- Sorbonne, Central Bank of Finland (Helsinki) and 2014 ASSET Conference (Aix-en-Provence) for valuable comments on previous versions. The usual disclaimer applies.
} 


\section{Introduction}

There is broad consensus among economists that (any) trade is better than (dominates) nontrade. Yet how trade takes place is often as important as whether it does. Integration can take a myriad of forms. The relationship between political and economic dimensions of regional integration has been recognized at least since Balassa's seminal work: "From the economic point of view, the basic question is not whether economic or political considerations gave the first impetus to the integration movement, but what the economic effects of integration are likely to be. In some political circles the economic aspects are deliberately minimized and the plan for economic integration is regarded merely as a pawn in the play of political forces (...) Even if political motives did have primary importance, this would not mean that the economist could not examine the relevant economic problems without investigating the elusive political issues" (Balassa, 1961, p.7). Recent scholarship focuses on these elusive political issues and, more specifically, on deep and shallow integration. ${ }^{1}$ Deep (joint economic and political) integration is associated with significantly larger and longer-lasting benefits than shallow (purely economic) integration. In this paper, we put forward an identification strategy that enables us to estimate the benefits from economic integration that are generated by political factors and by the complementarity between economics and politics. We call these the political economy benefits from regional integration and, to the best of our knowledge, this is the first paper to provide evidence that these net politically-driven economic benefits from integration exist and that they are nontrivial.

This paper contributes to the debate about the benefits of regional integration focusing on membership in the European Union (EU). The EU membership issue can be

\footnotetext{
1 See, among others, Baldwin and Jaimovich (2012), Brou and Ruta (2011), Liu and Ornelas (2014), Maggi and Rodríguez-Clare (2007), Mansfield et al. (2008), Martin et al. (2012), and Sapir (2011).
} 
divided in direct costs, indirect costs and benefits. Estimates of direct costs are not controversial (such figures are published yearly and for most net contributing member states this amounts to less than $1 \%$ of GDP). In contrast, there is no agreement on the nature and size of indirect costs (consider for example EU generated regulations). Regarding the estimates of the benefits, there is a disappointingly small econometric literature. Many believe, incorrectly, that this literature is vast because of the works on the benefits from trade liberalization, from the Single Market, and from the Euro. ${ }^{2}$ Yet studies on the overall benefits of membership itself are few and most of these few papers warn about the fragility of their own estimates. ${ }^{3}$ Henrekson et al. note that the estimates are "not completely robust" (1997, p. 1551), while Badinger (2005) also cautions that his estimates are "not completely robust" (p. 50). Crespo et al. (2008) find large growth effects from EU membership, but warn that country heterogeneity affects the robustness of their estimates. Moreover, the range of available estimates is too wide, going from a minimum of about 5 percent (Boltho and Eichengreen, 2008) gains in per capita income from EU accession, to a maximum of 20 percent gains (Badinger, 2005). Campos, Coricelli and Moretti (2014) use the synthetic control method (SCM) to estimate benefits from EU membership for 17 countries in the 1973, 1980s, 1995 and 2004 enlargements. They find net benefits tend to be significant and positive (with the exception of Greece) with per capita incomes of about 10 percent higher, on average in the first ten years of accession. In this paper, we extend the work of Campos et al. (2014) by separating the economic from political determinants of the benefits from integration.

The identification strategy focuses on the 1995 EU enlargement, characterized by the entry in the EU of three new member states (Austria, Finland and Sweden), and it rests

\footnotetext{
2 See, among others, Baldwin (1989), Baldwin and Seghezza (1996), and Frankel (2010), respectively.

3 Badinger and Breuss (2011) and Sapir (2011) survey the literature and note the paucity of empirical studies on the benefits of integration.
} 
on the fact that Norway, at the time of the 1995 Enlargement of the EU, had successfully completed accession negotiations, fulfilled all requirements for entry, had taken up membership in the European Economic Area (EEA) in January 1994 (with full access to the Single Market), but decided in a national referendum in November 1994 to reject fullfledged EU membership.

This strategy allows us to derive new evidence on political economy benefits of EU membership using both differences-in-differences and the SCM, the latter pioneered by Abadie et al. (2003). We use regional data for Austria, Finland and Sweden to construct "synthetic Norwegian regions" that voted "yes" to EU membership in 1995. The research question is what would be productivity levels in each of the regions of Norway if Norway had actually joined the EU in January 1995? The main finding is of positive, significant and substantial benefits in terms of productivity. If it had joined the EU in 1995, the average Norwegian region would have productivity levels about 6\% higher between 1995 and 2000. From the SCM, we find positive benefits from joining the EU in six out of the seven NUTS2 Norwegian regions. ${ }^{4}$ The Oslo region, which includes Norway's capital city, is the exception. We discuss various possible explanations for this exception and argue that these help shore up our identification strategy and interpretation of these estimated effects as the political economy benefits or politically-driven economic payoffs from integration.

The paper is organised as follows. The next section presents the identification strategy based upon the Norwegian experience with the 1995 EU enlargement. Section 3 describes the methodology and provides details of the regional data set. Section 4 presents baseline results and sensitivity checks. Section 5 concludes. An on-line appendix contains further estimation details and results from a wide range of robustness checks.

\footnotetext{
4 For details on Eurostat's Nomenclature of Territorial Units for Statistics (NUTS) see http://epp.eurostat.ec.europa.eu/portal/page/portal/nuts_nomenclature/introduction
} 


\section{Identification strategy}

The identification strategy we propose in this paper is based on the fact that at the time of the 1995 EU Enlargement, Norway was as ready to join the EU as Austria, Finland, and Sweden (the three countries that actually became EU members in 1995). Readiness is according to the official view of the EU after detailed accession negotiations. However, because all four countries were given full access to the Single Market in January 1994 as part of membership in the then newly created EEA, Norway ended up being fully economically integrated with the EU but not politically integrated. Thus, we argue that difference in returns between Norwegian regions (economically integrated only) and Austrian, Finnish and Swedish regions (economically and politically integrated) are the politically-driven economic benefits from membership.

The so-called Scandinavian EU enlargement is a truly unique and fascinating event. Austria, Finland and Sweden became full-fledged members of the EU on January $1^{\text {st }} 1995$. Because this is almost ten years after Spain and Portugal had joined (and almost fifteen years after Greece did), it is natural to ask why did it take so long. In terms of development of their political and economic institutions there is little doubt these countries have been ready to join for quite some time. Although they were able to enjoy some gains from integration as members of the European Free Trade Association (EFTA), even the earliest evidence shows that the EU was considerably more successful in this regard than EFTA (Aitken, 1973). Moreover, Sapir (2001) shows that “domino effects" were particularly strong for the 1995 enlargement: increased integration within the EU impacted outsiders negatively, thereby prompting their application for EU membership.

One key reason for this delay is the political context of the Cold War. Although Austria was a founding member of EFTA, "its desire, in 1961, to consider applying for the 
EEC was rejected by the USSR as an infringement of the 1955 State Treaty under which the Soviet Union -as one of the Four Allied Powers- had recognized Austrian independence with its permanent neutrality and prohibition from entering any union with Germany as the main preconditions" (Tatham, 2009, pp. 57-58). Austria applied for EU membership in June 1989. Sweden applied in 1991, Finland and Switzerland did it before the summer of 1992, while Norway applied in November 1992.

A crucial development in the run-up to the 1995 Enlargement was the EEA. In the late 1980s, EFTA States in general, and Sweden in particular, were looking for ways of further integrating with the more successful European Communities, with Swedish multinationals lobbying intensively. This met resistance from Brussels because the European Commission was fully occupied with the implementation of the Single Market. The compromise solution was a parallel structure that would allow EFTA members to participate in the EU's Internal Market (hence adopting all relevant legislation, with the exception of agriculture and fisheries) without participating in negotiations and without the need of applying for full-fledged membership (Barnes, 1996). Switzerland rejected EEA membership in a referendum in December 1992 causing the withdrawal of its application for EU membership. EEA membership was approved for Iceland, Norway, Austria, Finland and Sweden and became effective on January $1^{\text {st }} 1994$.

Norway applied for EU membership twice in the 1960s due to its strong trade links with the United Kingdom (UK). As the UK formal applications to EU membership in 1961 and 1967 were vetoed by France, Norway's also did not proceed. One of the most consequential events following the 1968 student protests in France was De Gaulle's resignation. Pompidou, his successor, had a different view of the process of European integration and encouraged the UK to submit a third application. A factor in this rapprochement was the growing influence of Germany in European affairs (as indicated by 
the 1969 Werner report on the monetary union). In October 1969, the European Commission published an "Opinion" recommending accession negotiation with the UK, Ireland, Denmark and Norway.

Accession negotiations with Ireland and Denmark were relatively smooth compared to those with the UK and Norway. Three items dominated Norway's agenda: agriculture, fisheries and regional policy. The permanent derogations Norway requested were not granted. Having accepted transitional periods for both agriculture (3 years) and fisheries (10 years), Norway signed the Accession Treaty and put it to a referendum in September 1972 (Tatham, 2009, p. 22). Its unexpected rejection (with 53.5\% votes against and 46.5\% in favour) represents a watershed moment in Norwegian history. Government resignation followed and a long-lasting political trauma engendered. After long periods under Danish (1319-1814) and Swedish (1814-1905) rules, Norwegians placed high value on their political independence. However, even if political preferences had not changed between 1967 and 1972, something else did: Norway discovered large reserves of oil in 1969.

The discovery of oil in 1969 (and the 1973 oil shock) radically transformed the Norwegian economy (Grytten, 2004). Energy became a major export and it also supported an increasing role for the public sector: the ratio of government expenditures to private consumption rose from $30 \%$ in 1970 to $40 \%$ in the early 1990s (OECD, 2014). Oil production peaked in 1993 but vast reserves of natural gas were activated in 1994, the year of a second EU referendum, resulting in oil and gas accounting "for just below 70 percent of total goods exports in 2011, up from about 50 percent in 1990" (IMF, 2013). As these are capitalintensive industries, employment issues can be severe. Signs of Dutch disease have been widely recognized yet deemed mild: "the data further suggests a two-tier development in the manufacturing sector in Norway, with industries linked to oil and gas expanding and other industries shrinking” (IMF, 2013). 
In this light, it is easy to see why the Norwegian government regarded energy as one of the areas of vital national importance in its negotiations with EU in the early 1990s (Archer, 2005). The other area considered of vital national importance was fisheries. Not only are herring, cod and salmon often associated with Norway around the world, but domestically fisheries evoke features of a distinctive Norwegian way of life. Fisheries have a large political role not reflected in its economic importance. The share of fisheries in total exports remained constant between 1990 and 2010 at 6\% (while the share of manufacturing halved). In the early 1990s negotiations, Norway secured a "Protocol to the Accession Agreement that would protect its sovereignty over its natural energy resources thereby keeping them out of the control of the EC" (Tathan, 2009, p.68). Yet, the EU did not grant exceptions for the Norwegian demands for equal access to waters and fishing stocks. The compromise reached was a transition period of 3 years. These were the EU membership terms presented to Norwegian voters in 1994. With turnout approaching 90\% of the electorate, EU membership was again rejected $(52.5 \%$ voted against it this time versus $53.5 \%$ in 1972). Only two of the seven major regions of Norway (NUTS2) voted "yes." Oslo had the greatest support for EU membership (65\% in favour), while the greatest share of "no" votes were in the northern-most region of Norway, which voted $72 \%$ against.

In summary, as of the 1995 enlargement Norway was in exact equal footing to join the EU as the other three countries that ended up joining (Austria, Finland and Sweden). Moreover, because of the EEA, Norway was in January 1994 granted access to the Single Market, a main source of economic benefits from integration. Yet, the rejection of fullfledged EU membership in the 1994 popular referendum left Norway as a country able to enjoy the bulk of the benefits from economic integration (through EEA), but not able to enjoy the benefits from political integration (through EU membership). This unique situation provides the basis for the econometric identification of politically-driven economic 
benefits from integration.

\section{Methodology and data}

In order to identify the politically-driven productivity benefits from EU integration we propose an identification strategy focusing on the 1995 enlargement and exploiting a panel of NUTS2 regions from Norway, Austria, Finland, and Sweden. Given the large shares of the oil and gas sectors on Norway's GDP, productivity provides a better measure of economic performance.

The basic idea is to compare the evolution of productivity in the Norwegian regions, which enjoyed the benefits from the EEA but not from full EU membership, with the evolution of productivity in the regions of the other three countries that in 1994 joined the EEA and in 1995 joined also the EU. In this way, we estimate what would have been the productivity gains for Norwegian regions had Norway joined the EU in 1995.

The comparison of the change in the average level of productivity (output per hour worked, in constant euros) before and after 1995 in each region of the four countries (Figure 1) reveals that while regions in Austria, Finland, and Sweden (with few exceptions) show very similar changes before and after, Norwegian regions display lower increase in average productivity compared to the regions of the other three countries, with the exception of the region of Oslo, which actually records the largest increase in the whole sample.

We test the significance of such productivity changes pre- versus post-1995 by constructing counterfactuals using two different yet complementary approaches: differences-in-differences and the synthetic control method (SCM), pioneered by Abadie and Gardeazabal (2003) and Abadie et al. $(2010,2014) .^{5}$

\footnotetext{
${ }^{5}$ Imbens and Wooldridge (2009) discuss the SCM among other recent developments in the econometrics of program evaluation, including differences-in-differences.
} 
In light of our identification strategy, the differences-in-differences approach allows to remove biases in the post-1995 comparison between Norwegian regions and Austrian, Finnish, and Swedish regions. These biases can result from permanent differences between the Norwegian and non-Norwegian regions and trends in the evolution of productivity. The differences-in-differences estimation contains a dummy variable representing the groups to be compared (in this case, the dummy variable takes the value of 1 for Norwegian regions, and zero otherwise) and also a dummy variable representing the period of comparison (in this case, the dummy variable takes the value of 1 one for the period post-1995, when Austria, Finland, and Sweden joined the EU, and zero for the period before-1995). We are mainly interested in the coefficient of the interaction between these two variables. The dummy variable for the Norwegian regions captures the pre-1995 differences between the two groups of regions, while the post-1995 dummy variable captures those factors that would have changed productivity in both groups of regions for reasons beyond EU or nonEU membership. The estimated coefficient of the interaction term hence represents the differences-in-differences estimation, obtained by subtracting the average change before and after 1995 of non-Norwegian regions to the average change over the same period of Norwegian regions. Everything else held equal, it can be interpreted as the effect of the choice of not joining the EU on the average productivity levels of Norwegian regions.

One well-known limitation of the differences-in-differences approach (Bertrand et al. 2004) is the need to assume that the differences between Norwegian regions and the comparison group would have remained constant in the absence of treatment. This amounts to assuming parallel trends, i.e., that the dynamics for one group does not differ from the dynamics for the other group. To deal with this limitation and to offer a more refined counterfactual scenario, we provide additional evidence from estimations obtained with the SCM. 
The SCM complements the differences-in-differences in several ways. First, it can provide a better pre-treatment match between Norwegian and control regions. Second, it better controls for the presence of time-variant unobserved heterogeneity (Abadie et al. 2010). Third, it is explicit about the individual weight of each donor region in the construction of the counterfactual of each treated unit. Fourth, it allows a detailed assessment of the dynamics of the effects from treatment over time, while the differences-indifferences offers before-and-after average effects. Finally, it allows us to estimate the heterogeneous effects of the treatment in each of the treated units.

The SCM compares the evolution of an aggregate outcome variable (productivity) for a given Norwegian region that has not joined the EU vis-à-vis the evolution of the same aggregate outcome for a "synthetic region that has joined the EU". The implementation of the SCM answers the question: "what would have been the level of productivity in each region after 1995 if Norway had become a full-fledged member of the EU?"

The SCM focuses on the construction of the "synthetic" or "artificial" control group (Imbens and Wooldridge, 2009, p. 72), by searching for a weighted combination of other units ("donor units", in this case regions in Austria, Finland and Sweden), which are chosen to match as close as possible a Norwegian region in the pre-treatment period, for a set of predictors of the outcome variable (productivity levels). The post-treatment evolution of the outcome for the synthetic control group is an estimate of the counterfactual. It shows what the behaviour of the outcome variable would have been for a Norwegian region if the intervention had happened in the same way as in the donor group. ${ }^{6}$ Here the elements in

\footnotetext{
${ }^{6}$ Abadie and Gardeazabal (2003) investigate "what would have been the levels of per capita GDP in the Basque country in Spain if it had not experienced terrorism?" Abadie et al. (2010) present two further examples: "what would have been cigarette consumption in California without Proposition 99?" and "what would have been the per capita GDP of West Germany without reunification?" (2014). Other recent papers using this method include Campos and Kinoshita (2010) on foreign direct investment, Lee (2011) on inflation targeting, Billmeier and Nannicini (2013) on trade liberalization, Acemoglu et al. (2014) on political connections, Campos et al. (2014) on EU membership, and Pinotti (2014) on mafia activities.
} 
the donor group are the regions of those three countries that have joined the EU in 1995: Austria, Finland, and Sweden.

The SCM represents an extension of the differences-in-differences framework by allowing the effects of unobserved variables on the outcome to vary over time. ${ }^{7}$ Moreover, it "allow(s) researchers to perform inferential exercises about the effects of the event or intervention of interest that are valid regardless of the number of available comparison units, the number of available time periods, and whether aggregate or individual data are used for the analysis" (Abadie et al., 2010). This method addresses endogeneity and omitted variable concerns but has as its main drawback the fact that it "does not allow assessing the significance of the results using standard (large-sample) inferential techniques, because the number of observations in the control pool and the number of periods covered by the sample are usually quite small in comparative case studies" (Billmeier and Nannicini, 2013, p. 987).

In this paper, we implement a simple yet novel solution to offer evidence on the confidence that can be attached to our results. We compare our main estimation with those obtained using a large number of alternative, and randomly chosen, donor samples. This also ensures our results are not driven by the inclusion of specific regions experiencing idiosyncratic shocks unrelated to EU membership. ${ }^{8}$

We use data from Cambridge Econometrics, which is a standard data reference in European regional studies. The Cambridge Econometrics European regional database covers NUTS2 regions for EU27 countries plus Norway and Switzerland. It includes variables for GDP, population, employment, investment, hours worked at the NUTS2 level and (broad) sector level. This database offers comparable data across regions and time over

\footnotetext{
${ }^{7}$ For a more formal discussion of this methodology see, among others, Abadie et al. (2010 and 2014), Imbens and Wooldridge (2009), Billmeier and Nannicini (2013), and Campos et al. (2014). We provide a brief formal presentation of the model in the Online Appendix.

${ }^{8}$ In the Online Appendix, for each Norwegian region, we also report results from placebo experiments.
} 
a sufficiently long pre- treatment period, and it has been widely used in regional economic analysis of the EU (see, among other, Becker et al. 2010, and Tabellini 2010). Using annual data from 1985 to 2000, we construct the following variables, all expressed at constant 2000 prices: productivity (GDP per hours worked), population density, investment rate (defined as the share of investment over GDP for the total regional economy), shares of employment in manufacturing, agriculture, and services over total regional employment. We also use a measure of years of education at the regional level from Gennaioli et al. (2014). Those variables represent the pre-treatment characteristics used for the construction of the synthetic counterfactual.

[Table 1 about here]

Eurostat's NUTS divides Norway in 7 regions at the two-digit level and 19 regions at the three-digit level. Existing data is available at two-digit level so we carry out our analysis for the seven NUTS2 regions of Norway. These regions are as follows: NO01 Oslo and Akershus (which includes the capital city and has the highest regional per capita GDP in Norway), NO02 Hedmark and Oppland (which is the only landlocked Norwegian region and has the lowest per capita GDP among Norwegian regions), NO03 Sør-Østlandet (second-lowest per capita GDP level among Norwegian regions), NO04 Agder and Rogaland (Rogaland is the center of the Norwegian Oil industry), NO05 Vestlandet (where Bergen is the main city and concentrates maritime research and shipping activities), NO06 Trøndelag (mostly agriculture and fisheries), and NO07 Nord-Norge (Northern-most region which makes up a third of Norwegian land mass, with fishing as main economic activity).

\section{Estimation results}

The objective of this section is to present our estimates of the politically-driven economic benefits from integration exploiting the fact that Norway is a country that is economically 
but not politically integrated with the EU. We assess the productivity effects of non-EU entry from 1995, which is the year of the Scandinavian enlargement, until 2000. One main benefit of stopping in 2000 is that our estimates do not reflect the effects of the introduction of the Euro (which was adopted in two out of the four countries included in this analysis, namely Austria and Finland). We first discuss the differences-in-differences estimation and then the results from the SCM.

\subsection{Differences-in-differences estimates}

Table 2 reports results from the differences-in-differences estimation. Our main interest is on the coefficient of the interaction between the dummy variable identifying the Norwegian regions (Norway) and the dummy variable identifying the treatment period (Post95). This coefficient shows the average change in productivity before and after 1995 for the Norwegian regions compared to the average change in Austrian, Finnish, and Sweden regions, over the same period.

[Table 2 about here]

Column 1 in Table 2 displays the results from the simplest specification, including

only the interaction and its two terms (a dummy for Norwegian regions and a dummy for the post-1995 period), column 2 includes region-fixed effects to control for time-invariant omitted variables at the regional level, column 3 adds year-fixed effects to control for annual shocks that are common across regions, and column 4 adds controls for time-varying regional level variables (such as the investment share, the sectoral shares of employment, population density, and education) to reduce problems arising from omitted time-varying variables.

The estimated coefficients of the interaction term $($ Norway*Post95) are negative and statistically significant. More importantly, the magnitude is relatively stable across all 
specifications. These estimates suggest that the average change before and after 1995 in the level of productivity in Norwegian regions was between 1.6 and 2 euros (or about 8 percent) lower that the average change before and after 1995 in regions of the three countries that joined the EU in 1995.

Because the Oslo region displays a distinct behaviour of average productivity (see Figure 1), columns 5 to 8 report results obtained excluding the region of Oslo from the sample. The results confirm the negative and statistically significant coefficients of the interaction term and, as expected, the magnitude of the effect is higher when Oslo is excluded.

\subsection{Synthetic control method (SCM) estimates}

The SCM estimates answer the counterfactual question that helps us make stronger causal statements on EU membership: what would be the productivity levels if Norway had joined the EU in 1995? Here SCM is applied to individual regions as it is an estimator for causal inference for comparative case studies. The Norwegian regions are the objective of the analysis, while the Austrian, Finnish, and Swedish regions form the donor pool used to construct the synthetic counterfactual for each Norwegian region.

Figure 2 summarizes the estimation results obtained with the SCM for the pretreatment (1985-1994) and post-treatment (1995-2000) differences in productivity between each Norwegian region and its synthetic counterfactual. The upper panel reports the differences in absolute values (in euros) with respect to the counterfactual, while the lower panel reports differences in percentage terms. During the pre-treatment period the actual and synthetic regions have very similar levels of productivity, while we estimate large differences for the post-treatment period. The estimated post-treatment differences between the actual and the synthetic regions are as follows: -1.7\% (-0.3 euro) for Trøndelag, -8.0\% (- 
1.9 euro) for Sør-Østlandet, -8.8\%, (-1.8 euro) for Hedmark og Oppland, -10.8\% (-2.8 euro) for Vestlandet, -12.4\% (-2.9 euro) for Nord-Norge, and -13.1\% (-3.5 euro) for Agder og Rogaland. Only for the Oslo region the post-treatment difference between the actual and synthetic region is positive ( $12.2 \%$ or 3.9 euro) ${ }^{9}$ It is encouraging that the average of these results is not far from the (average across regions) effect we estimate from differences-indifferences.

[Figure 2 about here]

Overall, these results show that during the period 1995-2000 GDP per hour worked in Norwegian regions with a hypothetical EU membership would have been, on average, about $6 \%$ higher than the actual level.

One explanation for why the SCM estimates differ from the differences-in-differences results is that the SCM accounts more fully for the presence of time-variant unobservable characteristics (Abadie et al. 2010).

Figure 3 shows the difference between the actual observed levels of productivity and our estimated counterfactuals. If the values post-1995 are negative (positive), productivity would be higher (lower) if that individual region were in a full-fledged member state of the EU. The figure clearly shows that the difference between productivity levels in actual and synthetic regions (the black line) is not constant but increases over time, which suggests that the politically-driven productivity benefits are not temporary. ${ }^{10}$

By construction, each region in the donor pool that takes a positive weight influences

\footnotetext{
9 We obtain similar results in the estimation of the synthetic counterfactual for the region of Oslo when we restrict the donor pool to the three regions of the capitals of Austria, Finland, and Sweden. See Figure A.1 in the Online Appendix.

${ }^{10}$ In Figure 3 we report our main results as the difference between the actual and synthetic regions over the period of analysis (black line). See Box A.1 to A.7 in the Online Appendix, for a different way of reporting the same results: graphs showing the dynamics of productivity of both the actual and synthetic regions. In the Online Appendix we also provide the weights taken by each region in the donor pool for the construction of the synthetic region, and the balance between the actual and synthetic regions in the pretreatment average values of the predictors.
} 
the post-treatment dynamics of the synthetic region and thus the estimated effects. One of the main concerns in estimating synthetic counterfactuals is that the results could be driven by an individual region in the donor pool experiencing an idiosyncratic shock, unrelated to the treatment. In order to control for this possibility, and assess whether the estimates are driven by the specific composition of the donor pool, we re-estimate iteratively the synthetic counterfactuals using a large number (set at one hundred) of alternative donor pools. Each alternative donor pool randomly selects half of the regions used for the baseline estimations (11 regions out of 22). The grey lines in Figure 3 represent these alternative estimations

[Figure 3 about here]

Figure 3 shows that the direction of the effect obtained in the baseline estimation is robust to different donor samples. If anything, the baseline estimations seem to underestimate the effects compared to this alternative (of random donor pools). Therefore, we conclude that the estimated productivity effects from our baseline estimations are not unduly driven by the specific composition of the donor pool. ${ }^{11}$

\subsection{Discussion}

The results presented above show that building relevant counterfactuals is a difficult but crucial step for policy oriented empirical analysis. Norway and the EU enlargement of 1995 provide a unique opportunity to further identify the drivers of the economic effects of political integration. Overall, the results suggest that combining economic and political integration (deep integration) leads to significant economic benefits in productivity terms.

\footnotetext{
${ }^{11}$ In the Online Appendix, we also report placebo tests on donor regions. Such placebo tests compare the effects on each Norwegian region with those obtained by subjecting the donor regions to the same treatment. Since in some donor region the pre-treatment mismatch with respect to its counterfactual is very large, we only report placebo results for those regions with a pre-treatment RMSPE smaller than three times the pre-treatment RMPSE of the Norwegian region in question. In most cases, the effect on the Norwegian region is greater than the effects on most of the donor regions.
} 
Moreover our results suggest that the net productivity benefits of deep integration seem larger than those from shallow integration. Using the differences-in-differences and SCM with regional Scandinavian data, we find substantial politically driven economic benefits from EU membership: if Norway had joined the EU in 1995, productivity levels between 1995 and 2000 would have been on average $6 \%$ higher.

Our results also suggest that such effects vary across regions. Regions, like Oslo, characterized by a high level of human capital and efficient public sector may reap benefits from economic integration, without the need of political integration. More peripheral regions, characterized by lower levels of human capital, by more rigid economic structures and by the presence of sectors of the economy protected from competition, may benefit from political integration if the latter means eliminating barriers to more efficient economic activity. In other words, exploiting the benefits of economic integration seem to require adequate policy responses when significant transformation of the local economy is necessary in the new, more integrated, economic environment. In the absence of such policy changes, benefits from economic integration may not be fully exploited. That political integration in the EU is a sufficient condition for such efficiency-enhancing policy response is obviously not warranted. However, in the specific case of Norway, political integration in the EU would have induced Norway to abandon continuing subsidization of low-productivity activities in the periphery of the country. The regions receiving large transfers to maintain their traditional economic model were those that rejected in the 1994 referendum fullfledged membership in the EU.

It is hard to provide strong evidence on our interpretation of the variability of results across Norwegian regions. Yet Figure 4 provides some hints supporting our interpretation. It suggests that the larger is the share of employment in energy and traditional (fisheries) sectors, the higher is the productivity loss due to non-entry, while the opposite applies to 
regions with large share of employment in financial services and public administration.

[Figure 4 about here]

Maintaining more independence in agricultural, fishing and energy sectors was the main force behind the democratic decision to say no to EU entry. It is conceivable that people do not tend to vote having as their main objective the achievement of higher economic efficiency (productivity). Attachment to the traditional Norwegian way of life and continuing traditional activities were of great importance in voting behaviour in the Norwegian EU referenda (Skinner, 2012). Attachment to national independence played a role as well in a country until relatively recently dominated by foreign nations. We add to such explanations the economic objective of continuing to receive large transfers and of controlling unemployment in general (and, more specifically, protecting employment in traditional activities) likely played an important role. In this respect, Norway is a singular case regarding the implications of EU accession for regional policies. Indeed, poorer countries in the EU faced a different situation, with accession implying large transfers of resources to peripheral regions through cohesion and structural funds (while these national subsidies in Norway were considerably larger than those offered by the EU). Accordingly, the Norwegian experience cannot be used as a model for countries that consider the option to exit the EU. Moreover, Norway and the EU have a deep and extensive relationship involving financial flows of magnitudes comparable to those of other "official" member states (Norwegian Ministry of Foreign Affairs, 2012). The EU-Norway relationship has been described as "tight incorporation without formal membership" and equated with a sharecropper's arrangement (Fossum, 2009). Nevertheless, we find no evidence in the Norwegian case of dominant economic benefits from the non-EU membership option.

In sum, political integration may help break local and regional support against policies fostering economic efficiency, even though this effect varies across types of policies. 
Political integration in the EU is incomplete and thus national governments retain significant independence on a wide range of economically relevant policies. However, regarding reduction of direct subsidies to specific sectors and thus in terms of competition policy, EU policies seem powerful. In fact, through its participation in the EEA, the EU influences policies in Norway. For instance, the EU has eventually succeeded in forcing Norway to eliminate its system of special taxation of remote areas meant to subsidize employment.

\section{Conclusions}

The Great Recession and the European Crisis have ignited an intensive re-examination of the costs and benefits of European Integration. Although economists recognize that integration that combines economic and political aspects tend to be deeper (and also tend to generate larger, more sustained and sustainable welfare gains), it remains a huge challenge to correctly identify and estimate additional benefits from deeper integration. This paper contributes to this effort. It uses the Norwegian experience to provide a monetary estimate of the political economy benefits of economic integration. We defined political economy benefits as the economic effects from the pure political integration plus the economic effects of the interaction between the political and economic integration. In this sense, we estimate the politically-driven productivity payoffs from integration.

Our identification strategy relies on the fact that Norway by the time of the 1995 Enlargement of the EU, had fulfilled all requirements for EU entry including membership in the EEA (with gave it full access to the Single Market and to all economic benefits from pure economic integration) but in a referendum voted to reject full-fledged EU membership. This paper used differences-in-differences and the synthetic control method with regional data for Austria, Finland and Sweden to construct "synthetic" Norwegian regions. 
Comparing productivity levels between actual Norway and synthetic, hypothetical or counterfactual Norway generates our measure of the political economy benefits from integration.

We find substantial benefits from EU membership: if Norway had joined the EU in 1995, productivity levels (GDP per hour worked) in the average Norwegian region between 1995 and 2000 would have been 6\% higher. For only one of the seven NUTS2 regions of Norway, the Oslo region, we estimate negative political economy benefits. Unsurprisingly, excluding Oslo, if Norway had joined the EU in 1995, productivity levels (GDP per hour worked) in the average Norwegian region between 1995 and 2000 would have been 9\% higher instead. We believe this finding about Oslo further strengthens our identification strategy and interpretation of the results. Our results suggest that these politically-driven payoffs are significant, substantial and distinctively favor deep (economic and political) over shallow (only economic) integration. 


\section{References}

Abadie, A., A. Diamond, and J. Hainmueller (2010), "Synthetic Control Methods for Comparative Case Studies: Estimating the Effect of California's Tobacco Control Program," Journal of American Statistical Association 105(490): 493-505.

Abadie, A., A. Diamond, and J. Hainmueller (2014), "Comparative Politics and the Synthetic Control Method,” American Journal of Political Science, doi: 10.1111/ajps.12116.

Abadie, A., and J. Gardeazabal (2003), "The Economic Costs of Conflict: A Case Study of the Basque Country," American Economic Review 93(1): 113-132.

Acar, S. and B.C. Karahasan (2013). "Uncovering Norway? Regional Disparities With Respect To Natural Riches," ERSA conference papers ersa13p723, European Regional Science Association.

Acemoglu, D., S. Johnson, A. Kermani, J. Kwak and T. Mitton (2014), "The Value of Connections in Turbulent Times: Evidence from the United States," MIT mimeo.

Aitken, N. (1973), "The Effect of the EEC and EFTA on European Trade: A Temporal CrossSection Analysis," American Economic Review 63(5): 881-892.

Archer, C. (2005), Norway Outside the European Union: Norway and European Integration from 1994 to 2004, London: Routledge.

Badinger, H. (2005), "Growth Effects of Economic Integration: Evidence from the EU Member States," Review of World Economics 141(1): 50-78.

Badinger, H. and F. Breuss (2010), "Quantitative Effects of European Post-war Economic Integration," in International Handbook on the Economics of Integration (v3), Palgrave.

Balassa, B. (1961), The Theory of Economic Integration, Richard Irwin, Homewood, Illinois.

Baldwin, R. (1989), “The Growth Effects of 1992,” Economic Policy 4(9): 247-281.

Baldwin, R. and D. Jaimovich (2012), “Are Free Trade Agreements Contagious?" Journal of International Economics 88(1): 1-16.

Baldwin, R.E. and E. Seghezza (1996), "Growth and European Integration: Towards an Empirical Assessment,” CEPR Discussion Paper No. 1393.

Barnes, I. (1996), "Agriculture, Fisheries and the 1995 Nordic Enlargement", in L. Miles (ed). The European Union and the Nordic Countries, London: Routledge.

Becker, S., P. Egger, and M. von Ehrlich (2010), "Going NUTS: The Effect of EU Structural Funds on Regional Performance," Journal of Public Economics 94(9-10): 578-590.

Bertrand M., E. Duflo and S. Mullainathan (2004), "How Much Should We Trust Differences-in-Differences Estimates?" Quarterly Journal of Economics 119 (1): 249-275. 
Billmeier, A. and T. Nannicini (2013), "Assessing Economic Liberalization Episodes: A Synthetic Control Approach," Review of Economics and Statistics, 95(3): 983-1001.

Brou, D. and M. Ruta (2011), "Economic Integration, Political Integration or Both?" Journal of the European Economic Association 9(6): 1143-1167.

Boltho, A. and B. Eichengreen (2008), "The Economic Impact of European Integration," CEPR Discussion Paper No. 6820.

Campos, N., F. Coricelli, and L. Moretti (2014), "Economic Growth and Political Integration: Estimating the Benefits from Membership in the European Union”, CEPR DP 9968.

Campos, N. and Y. Kinoshita (2010), "Structural Reforms, Financial Liberalization and Foreign Direct Investment," IMF Staff Papers 57(2): 326-365.

Crespo, J., M. Silgoner, and D. Ritzberger-Grünwald (2008), "Growth, Convergence and EU Membership", Applied Economics, 40: 643-656.

Fossum, J. E. (2009). "Norway's European conundrum," Arena Discussion Paper 4, University of Oslo.

Frankel, J. (2010), "The Estimated Trade Effects of the Euro: Why Are They Below Those from Historical Monetary Unions among Smaller Countries?" in Alesina, A. and F. Giavazzi (eds.), Europe and the Euro, Chicago: University of Chicago Press.

Gennaioli N., R. La Porta, F. Lopez De Silanes, and A. Shleifer (2014). "Growth in Regions," Journal of Economic Growth 19(3): 259-309.

Grytten, O.H. (2004), “The Gross Domestic Product for Norway, 1830-2003.” in Ø. Eitrheim, J.T. Klovland, and J.F. Qvigstad (eds). Historical Monetary Statistics for Norway, 18192003, Oslo: Norges Bank.

Henrekson, M., J. Torstensson, and R. Torstensson (1997), "Growth Effects of European Integration," European Economic Review 41(8): 1537-1557.

House of Commons (2013), "Norway's relationship with the EU," London: UK House of Commons Library Standard Note SN06522.

Imbens, G. and J. Wooldridge (2009), "Recent Developments in the Econometrics of Program Evaluation," Journal of Economic Literature 47(1): 5-86.

IMF International Monetary Fund (2013), "Norway 2013 Article IV Consultation: Selected Issues,” IMF Country Report No. 13/273.

Lee, W. (2011), "Comparative Case Studies of the Effects of Inflation Targeting in Emerging Economies," Oxford Economic Papers 63(2): 375-397. 
Liu, X. and E. Ornelas (2014), "Free Trade Agreements and the Consolidation of Democracy," American Economic Journal: Macroeconomics, 6(2): 29-70.

Maggi, G. and A. Rodríguez-Clare (2007), "A Political-Economy Theory of Trade Agreements," American Economic Review 97(4), 1374-1406.

Mansfield, E., H. Milner and J. Pevehouse (2008), "Democracy, Veto Players, and the Depth of Regional Integration," World Economy 31(1), 67-96.

Martin, P., T. Mayer and M. Thoenig (2012), "The Geography of Conflicts and Regional Trade Agreements," American Economic Journal: Macroeconomics 4(4): 1-35.

Norwegian Ministry of Foreign Affairs (2012), EEA Agreement and Norway's other agreements with the EU [http://www.eu-norway.org/news1/Norway-the-EEA-Agreementand-Norways-other-agreements-with-the-EU/]

OECD (2014), Economic Survey of Norway 2014, Paris: OECD.

Pinotti, P. (2014). "The Economic Costs of Organized Crime: Evidence from Southern Italy", Economic Journal, forthcoming.

Sapir, A. (2001), "Domino Effects in Western European Regional Trade, 1960-1992," European Journal of Political Economy, 17(2): 377-388.

Sapir, A (2011), "European Integration at the Crossroads: A Review Essay on the 50th Anniversary of Bela Balassa's Theory of Economic Integration", Journal of Economic Literature, 49(4): 1200-1229.

Skinner, M. S. (2012), "Norwegian Euroscepticism: Values, Identity or Interest", Journal of Common Market Studies 50(3): 422-440.

Tabellini, G. (2010), "Culture and Institutions: Economic Development in the Regions of Europe," Journal of the European Economic Association 8(4): 677-716.

Tatham, A. (2009), Enlargement of the European Union, Amsterdam: Kluwer European Law Collection. 
Table 1: Summary statistics.

\begin{tabular}{|c|c|c|c|c|c|c|c|c|c|c|}
\hline \multirow[b]{2}{*}{ Variable } & \multicolumn{5}{|c|}{$\begin{array}{l}\text { Norwegian } \\
\text { regions }\end{array}$} & \multicolumn{5}{|c|}{$\begin{array}{l}\text { Austrian, Finnish, and Swedish } \\
\text { regions }\end{array}$} \\
\hline & Obs & Mean & $\mathrm{SD}$ & Min & Max & Obs & Mean & SD & Min & Max \\
\hline & \multicolumn{10}{|c|}{$1985-1994$} \\
\hline Productivity & 70 & 20.46 & 3.43 & 14.56 & 31.10 & 220 & 21.91 & 4.04 & 13.95 & 31.33 \\
\hline Share of manufacturing & 70 & 0.17 & 0.05 & 0.10 & 0.26 & 220 & 0.21 & 0.05 & 0.07 & 0.32 \\
\hline Share of agriculture & 70 & 0.08 & 0.04 & 0.00 & 0.17 & 220 & 0.11 & 0.07 & 0.00 & 0.31 \\
\hline Share of services & 70 & 0.35 & 0.08 & 0.26 & 0.54 & 220 & 0.32 & 0.08 & 0.21 & 0.50 \\
\hline Population density & 70 & 0.03 & 0.05 & 0.00 & 0.17 & 220 & 0.22 & 0.74 & 0.00 & 3.74 \\
\hline Investment share & 70 & 0.24 & 0.03 & 0.19 & 0.28 & 220 & 0.22 & 0.04 & 0.12 & 0.40 \\
\hline \multirow[t]{2}{*}{ Education } & 70 & 8.58 & 0.39 & 7.79 & 9.41 & 220 & 10.11 & 0.42 & 9.12 & 10.98 \\
\hline & \multicolumn{10}{|c|}{$1995-2000$} \\
\hline Productivity & 42 & 23.41 & 5.32 & 18.66 & 38.15 & 132 & 26.84 & 4.23 & 18.10 & 37.95 \\
\hline Share of manufacturing & 42 & 0.16 & 0.05 & 0.09 & 0.23 & 132 & 0.19 & 0.05 & 0.09 & 0.29 \\
\hline Share of agriculture & 42 & 0.06 & 0.03 & 0.00 & 0.12 & 132 & 0.07 & 0.05 & 0.00 & 0.24 \\
\hline Share of services & 42 & 0.36 & 0.07 & 0.28 & 0.54 & 132 & 0.34 & 0.08 & 0.24 & 0.54 \\
\hline Population density & 42 & 0.04 & 0.06 & 0.00 & 0.18 & 132 & 0.23 & 0.77 & 0.00 & 3.73 \\
\hline Investment share & 42 & 0.25 & 0.02 & 0.21 & 0.30 & 132 & 0.21 & 0.04 & 0.08 & 0.35 \\
\hline Education & 42 & 9.54 & 0.26 & 9.03 & 10.08 & 132 & 10.25 & 0.67 & 8.72 & 11.35 \\
\hline
\end{tabular}

VARIABLES' DEFINITIONS AND DATA SOURCES: Productivity is GDP (at 2000 constant prices) per hour worked: (GDP/total employment*hours per employee per week*52 weeks); Share of manufacturing is the share of employment in energy and manufacturing on total employment; Share of agriculture is the share of employment in agriculture on total employment; Share of services is the share of employment in services (distribution, hotel \& restaurants, transport, storage and communications, financial intermediation, real estate, renting and business activities) on total employment; Population density is the ratio between population and area of the region; Investment share is the ratio between total investment and GDP. Education are the years of schooling. 
Figure 1: Within region difference in productivity post vs pre-1995.

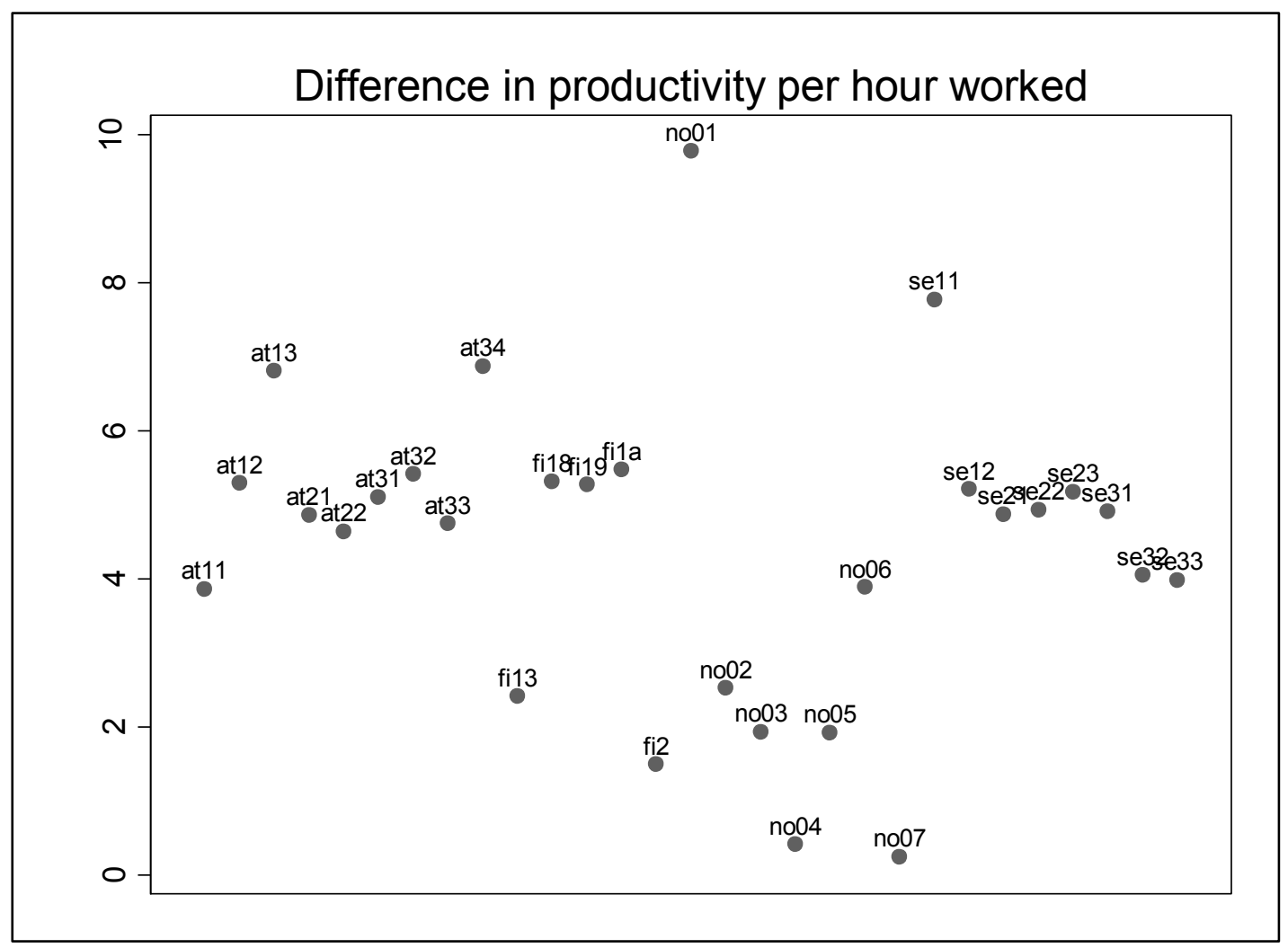

Note:

See Table 1 for variables' definitions. 
Table 2: Differences-in-Differences estimations on regional-level data (1985-2000).

\begin{tabular}{|c|c|c|c|c|c|c|c|c|}
\hline \multirow{3}{*}{$\begin{array}{l}\text { Dependent } \\
\text { variable } \\
\text { Sample } \\
\text { Columns } \\
\end{array}$} & \multicolumn{8}{|c|}{ Productivity (GDP per hour worked) } \\
\hline & \multicolumn{4}{|c|}{ All regions } & \multicolumn{4}{|c|}{ All regions but Oslo } \\
\hline & $(1)$ & $(2)$ & $(3)$ & $(4)$ & $(5)$ & $(6)$ & $(7)$ & $(8)$ \\
\hline Norway * Post95 & $\begin{array}{l}-1.97^{*} \\
(1.02)\end{array}$ & $\begin{array}{c}-1.97 * * * \\
(0.44)\end{array}$ & $\begin{array}{c}-1.97 * * * \\
(0.40)\end{array}$ & $\begin{array}{c}-1.59 * * * \\
(0.38)\end{array}$ & $\begin{array}{c}-3.11^{* * * *} \\
(0.62)\end{array}$ & $\begin{array}{c}-3.11^{* * *} \\
(0.28)\end{array}$ & $\begin{array}{c}-3.11^{* * *} \\
(0.25)\end{array}$ & $\begin{array}{c}-2.47 * * * \\
(0.29)\end{array}$ \\
\hline Norway & $\begin{array}{c}-1.45^{* * *} \\
(0.49)\end{array}$ & & & & $\begin{array}{c}-2.35^{* * *} \\
(0.43)\end{array}$ & & & \\
\hline Post95 & $\begin{array}{c}4.93 * * * \\
(0.46)\end{array}$ & $\begin{array}{c}4.93 * * * \\
(0.18)\end{array}$ & & & $\begin{array}{c}4.93 * * * \\
(0.46)\end{array}$ & $\begin{array}{c}4.93 * * * \\
(0.18)\end{array}$ & & \\
\hline Constant & $\begin{array}{c}21.91^{* * * *} \\
(0.27)\end{array}$ & $\begin{array}{c}21.56^{* * *} \\
(0.11)\end{array}$ & $\begin{array}{c}19.57^{* * * *} \\
(0.28)\end{array}$ & $\begin{array}{c}5.42 \\
(4.85)\end{array}$ & $\begin{array}{c}21.91^{* * *} \\
(0.27)\end{array}$ & $\begin{array}{c}21.41^{* * *} \\
(0.11)\end{array}$ & $\begin{array}{c}19.46^{* * *} \\
(0.23)\end{array}$ & $\begin{array}{l}8.23^{*} \\
(4.63)\end{array}$ \\
\hline Region FE & & $\mathrm{X}$ & $\mathrm{X}$ & $\mathrm{X}$ & & $\mathrm{X}$ & $\mathrm{X}$ & $\mathrm{X}$ \\
\hline Year FE & & & $\mathrm{X}$ & $\mathrm{X}$ & & & $\mathrm{X}$ & $\mathrm{X}$ \\
\hline Controls RY & & & & $\mathrm{X}$ & & & & $\mathrm{X}$ \\
\hline Observations & 464 & 464 & 464 & 464 & 448 & 448 & 448 & 448 \\
\hline R-squared & 0.25 & 0.87 & 0.93 & 0.94 & 0.32 & 0.88 & 0.95 & 0.96 \\
\hline Mean outcome & 23.23 & 23.23 & 23.23 & 23.23 & 23.00 & 23.00 & 23.00 & 23.00 \\
\hline \multicolumn{9}{|c|}{$\begin{array}{l}\text { Note: Robust standard errors in parentheses. Inference: } * * * \mathrm{p}<0.01, * * \mathrm{p}<0.05, * \mathrm{p}<0.1 \text {. Norway is a dummy } \\
\text { variable that takes the value } 1 \text { for Norwegian regions, the value } 0 \text { for Austrian, Finnish, and Swedish regions. } \\
\text { Post95 is a dummy variable that takes the value } 1 \text { for years from } 1995 \text { to } 2000 \text {, the value } 0 \text { for years from } 1985 \\
\text { to } 1994 \text {. Controls RY is a set of control variables with region-year dimension (such as the shares of industries } \\
\text { employment on total employment, population density, investment share, education). See Table } 1 \text { for variables' } \\
\text { definitions and Table A.1 in the Online Appendix reports estimated coefficients of all the control variables } \\
\text { included in columns } 4 \text { and } 8 \text {. }\end{array}$} \\
\hline
\end{tabular}


Figure 2: Summary of baseline estimations (synthetic control method, SCM).

\section{Difference $(€)$ between actual and synthetic}

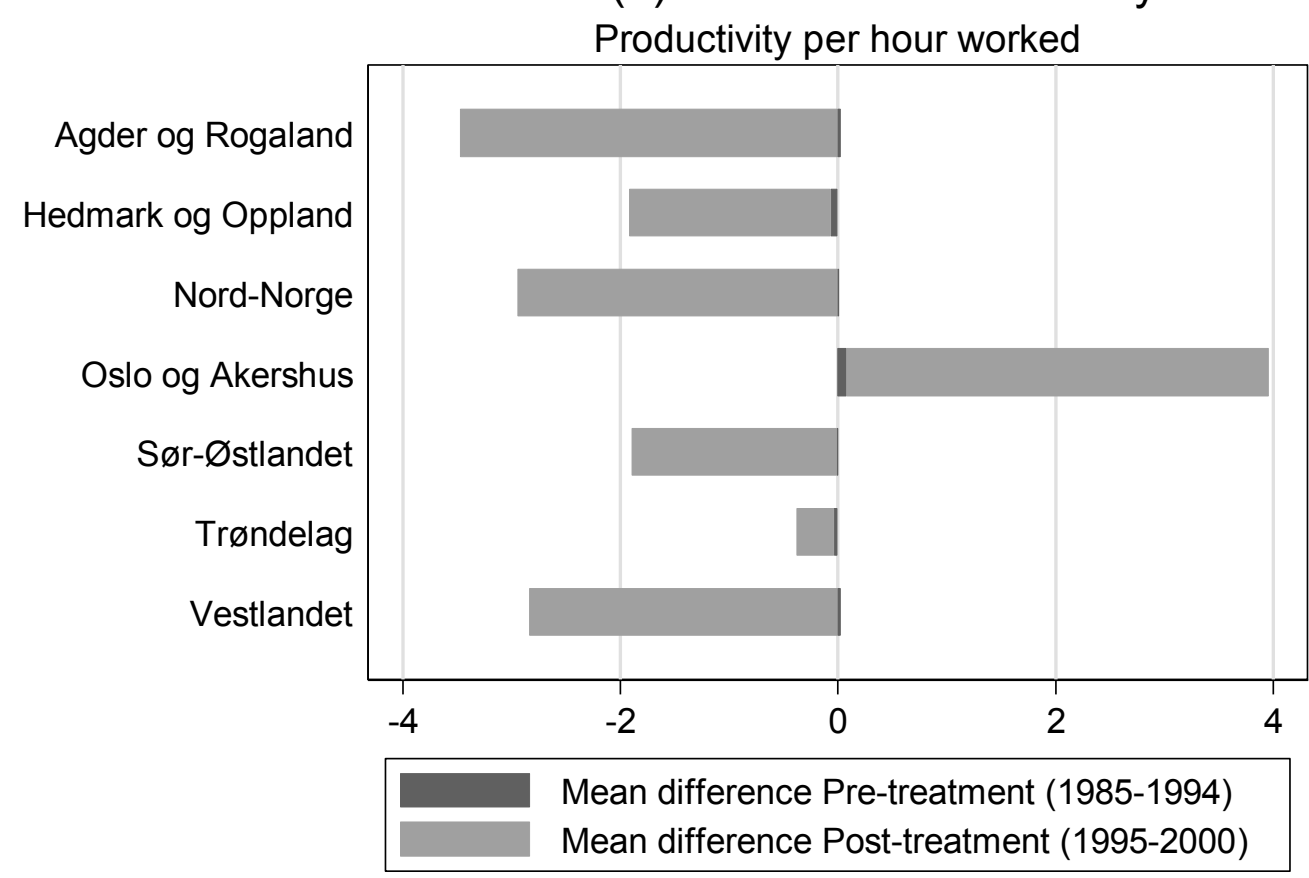

Difference (\%) between actual and synthetic

Productivity per hour worked

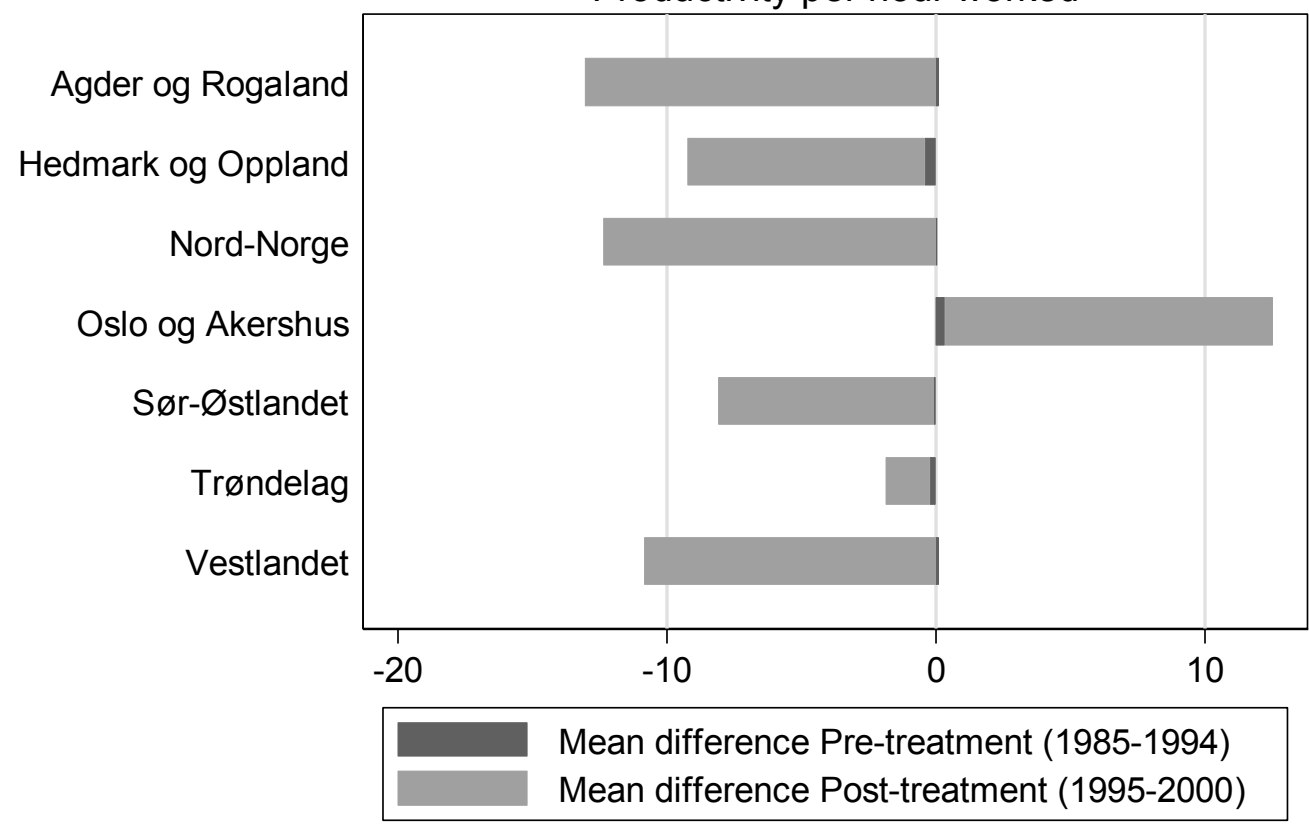

Note:

See Table 1 for variables' definitions. 
Figure 3: Estimations from the SCM using randomly chosen donor samples.
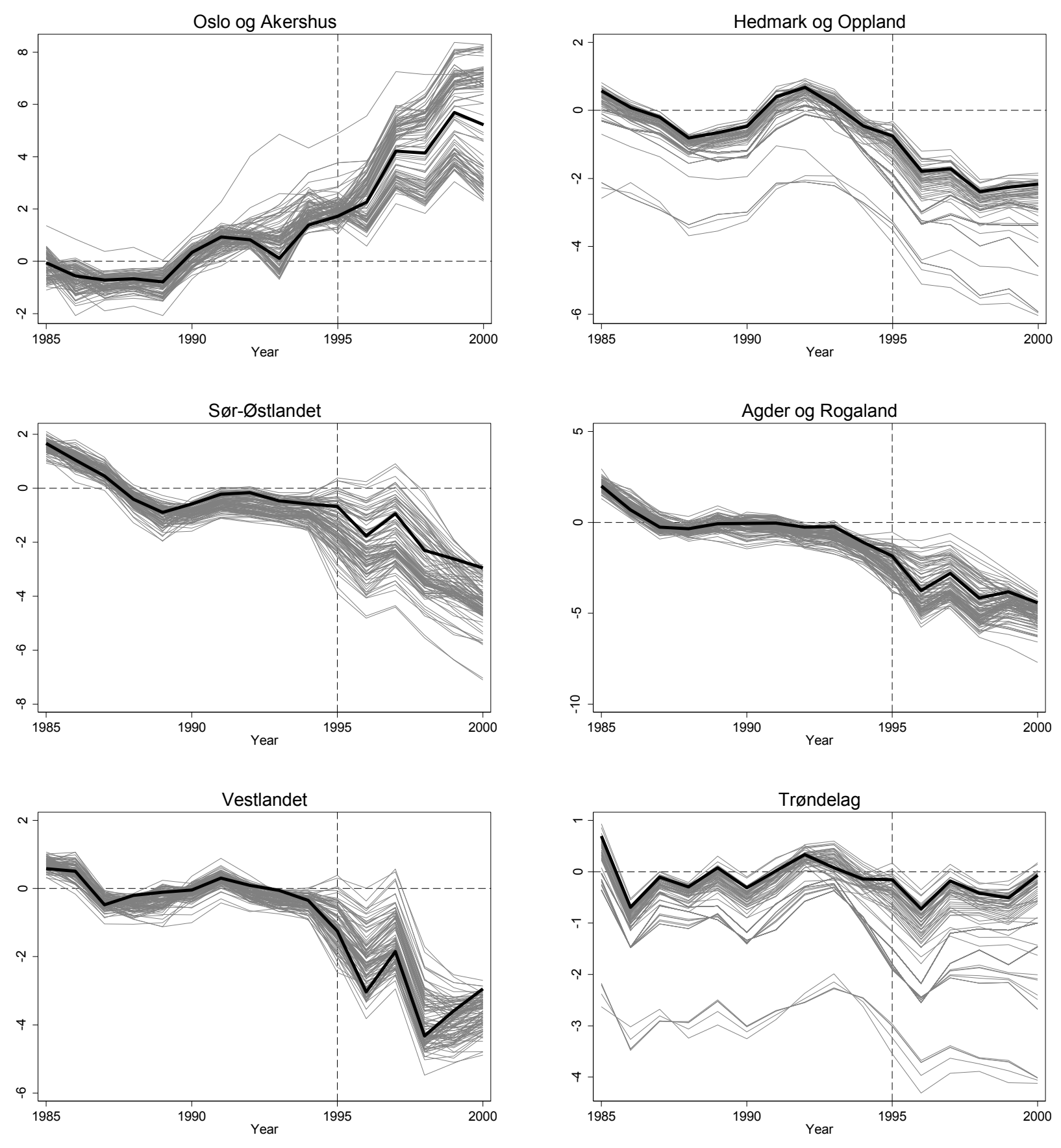


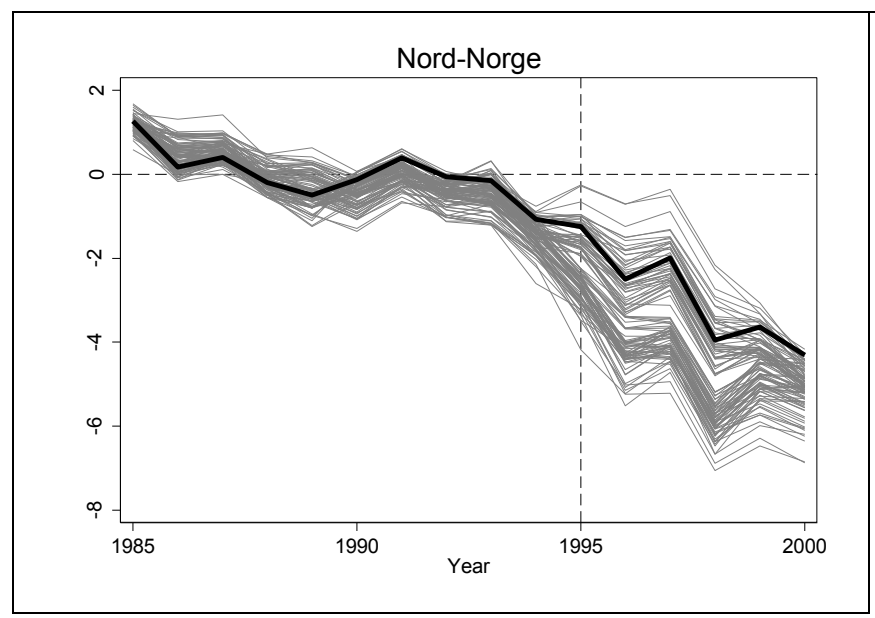

Note: See Table 1 for variables' definitions. In each graph, on the y-axis there is the difference (in euros) between the actual and synthetic region. The black line represents our baseline estimation that is obtained using in the donor sample all of the 22 NUTS2 regions of Austria, Finland, and Sweden (See Box A.1 to A.7 in On-line Appendix for further details). The grey lines represent 100 alternative estimations that are obtained using in the donor sample 11 regions randomly chosen from the pool of 22 NUTS2 regions of Austria, Finland, and Sweden. 
Figure 4: Correlation between estimated effects from the synthetic control methods (SCM) and sector employment over population
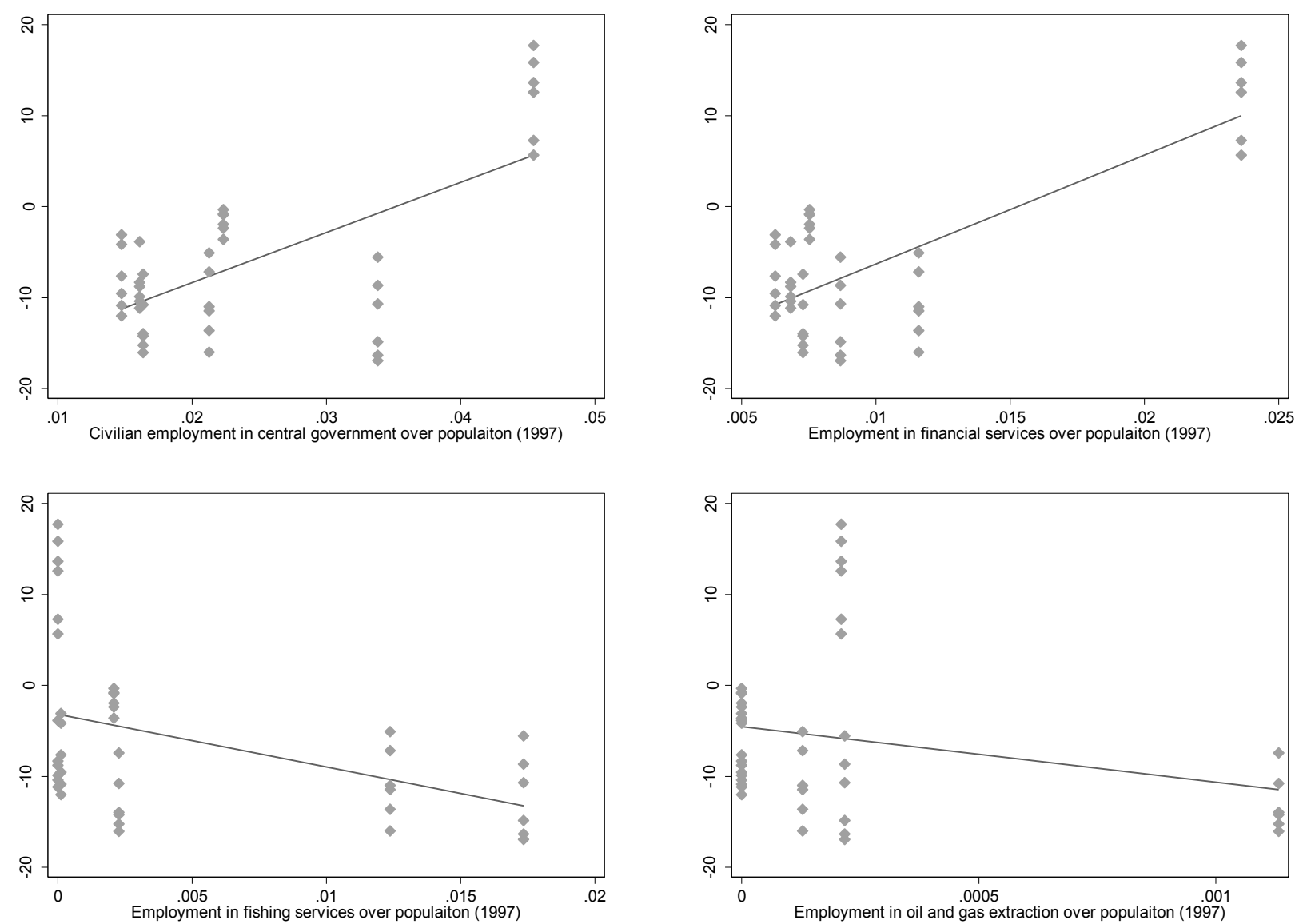

Note: The percentage gap is the results of our own SCM estimations. Employment shares are from Acar and Karahasan (2013). 
On-line Appendix

(Not for publication) 


\section{Table A.1. Robustness checks: Differences-in-Differences estimations on regional- level data (1985-2000).}

\begin{tabular}{|c|c|c|c|c|c|c|}
\hline \multirow{2}{*}{$\begin{array}{l}\text { Dependent variable } \\
\text { Sample } \\
\text { Columns }\end{array}$} & \multicolumn{6}{|c|}{ Productivity (GDP per hour worked) } \\
\hline & \multicolumn{3}{|c|}{ All regions } & \multicolumn{3}{|c|}{ All regions but Oslo } \\
\hline Norway * Post95 & $\begin{array}{c}-1.65^{* *} \\
(0.80)\end{array}$ & $\begin{array}{c}-1.37 * * * \\
(0.45)\end{array}$ & $\begin{array}{c}-1.59 * * * \\
(0.38)\end{array}$ & $\begin{array}{c}-3.15^{* * *} \\
(0.47)\end{array}$ & $\begin{array}{c}-2.36^{* * *} \\
(0.31)\end{array}$ & $\begin{array}{c}-2.47^{* * *} \\
(0.29)\end{array}$ \\
\hline Norway & $\begin{array}{c}-1.54^{* * *} \\
(0.52)\end{array}$ & & & $\begin{array}{c}-2.06^{* * * *} \\
(0.50)\end{array}$ & & \\
\hline Post95 & $\begin{array}{c}2.83^{* * * *} \\
(0.22)\end{array}$ & $\begin{array}{c}3.02^{* * * *} \\
(0.20)\end{array}$ & & $\begin{array}{c}3.04^{* * * *} \\
(0.19)\end{array}$ & $\begin{array}{c}2.87 * * * \\
(0.19)\end{array}$ & \\
\hline Share of manufacturing & $\begin{array}{c}-13.95^{* * *} \\
(2.17)\end{array}$ & $\begin{array}{c}-40.96^{* * *} \\
(10.02)\end{array}$ & $\begin{array}{c}3.07 \\
(8.45)\end{array}$ & $\begin{array}{c}-14.24^{* * *} \\
(2.09)\end{array}$ & $\begin{array}{c}-39.19 * * * \\
(9.39)\end{array}$ & $\begin{array}{c}-2.54 \\
(7.84)\end{array}$ \\
\hline Share of agriculture & $\begin{array}{c}-54.90^{* * *} \\
(3.31)\end{array}$ & $\begin{array}{c}-21.22^{* * * *} \\
(6.21)\end{array}$ & $\begin{array}{c}28.65^{* * *} \\
(6.59)\end{array}$ & $\begin{array}{c}-57.41^{* * *} \\
(2.67)\end{array}$ & $\begin{array}{c}-24.17 * * * \\
(5.72)\end{array}$ & $\begin{array}{c}18.26^{* * * *} \\
(5.65)\end{array}$ \\
\hline Share of services & $\begin{array}{c}-10.02^{* * * *} \\
(3.37)\end{array}$ & $\begin{array}{c}12.40 \\
(11.45)\end{array}$ & $\begin{array}{c}27.43^{* * * *} \\
(9.46)\end{array}$ & $\begin{array}{c}-18.88^{* * *} \\
(2.56)\end{array}$ & $\begin{array}{c}17.55 \\
(10.83)\end{array}$ & $\begin{array}{c}29.46^{* * * *} \\
(9.04)\end{array}$ \\
\hline Population density & $\begin{array}{c}-0.59^{* * *} \\
(0.20)\end{array}$ & $\begin{array}{c}27.85^{* * *} \\
(4.64)\end{array}$ & $\begin{array}{c}13.83^{* * *} \\
(3.61)\end{array}$ & $\begin{array}{l}-0.30 \\
(0.19)\end{array}$ & $\begin{array}{c}22.34^{* * *} \\
(3.10)\end{array}$ & $\begin{array}{c}11.39 * * * \\
(2.59)\end{array}$ \\
\hline Investment share & $\begin{array}{c}-25.08^{* * *} \\
(4.44)\end{array}$ & $\begin{array}{c}-13.36^{* * *} \\
(5.03)\end{array}$ & $\begin{array}{c}-6.20 \\
(4.45)\end{array}$ & $\begin{array}{c}-19.06^{* * *} \\
(3.95)\end{array}$ & $\begin{array}{c}-13.04^{* *} \\
(5.08)\end{array}$ & $\begin{array}{l}-7.47 \\
(4.64)\end{array}$ \\
\hline Education & $\begin{array}{c}0.80 * * * \\
(0.25)\end{array}$ & $\begin{array}{l}0.45^{*} \\
(0.23)\end{array}$ & $\begin{array}{c}0.04 \\
(0.18)\end{array}$ & $\begin{array}{c}0.68^{* * *} \\
(0.23)\end{array}$ & $\begin{array}{c}0.30 \\
(0.22)\end{array}$ & $\begin{array}{c}0.01 \\
(0.17)\end{array}$ \\
\hline Constant & $\begin{array}{c}31.39 * * * \\
(2.41)\end{array}$ & $\begin{array}{c}21.50 * * * \\
(6.30)\end{array}$ & $\begin{array}{c}5.42 \\
(4.85)\end{array}$ & $\begin{array}{c}34.33^{* * * *} \\
(2.16)\end{array}$ & $\begin{array}{c}22.26^{* * *} \\
(5.96)\end{array}$ & $\begin{array}{l}8.23^{*} \\
(4.63)\end{array}$ \\
\hline $\begin{array}{l}\text { Region FE } \\
\text { Year FE }\end{array}$ & & $\mathrm{X}$ & $\begin{array}{l}\mathrm{X} \\
\mathrm{X} \\
\end{array}$ & & $\mathrm{X}$ & $\begin{array}{l}X \\
X \\
\end{array}$ \\
\hline Observations & 464 & 464 & 464 & 448 & 448 & 448 \\
\hline R-squared & 0.78 & 0.91 & 0.94 & 0.85 & 0.94 & 0.96 \\
\hline Mean outcome & 23.23 & 23.23 & 23.23 & 23.00 & 23.00 & 23.00 \\
\hline
\end{tabular}

Note: Robust standard errors in parentheses. Inference: ${ }^{* * *} \mathrm{p}<0.01,{ }^{* *} \mathrm{p}<0.05,{ }^{*} \mathrm{p}<0.1$. Norway is a dummy variable that takes the value 1 for Norwegian regions, the value 0 for Austrian, Finnish, and Swedish regions. Post95 is a dummy variable that takes the value 1 for years from 1995 to 2000, the value 0 for years from 1985 to 1994. See Notes on Box A.1 to A.7 for other variables' definitions. 
Table A.2. Robustness checks: Differences-in-Differences estimations on regionallevel data (1985-2000).

\begin{tabular}{|c|c|c|c|c|c|c|}
\hline \multirow{3}{*}{$\begin{array}{l}\text { Dependent variable } \\
\text { Sample } \\
\text { Columns }\end{array}$} & \multicolumn{6}{|c|}{ Ln (Productivity: GDP per hour worked) } \\
\hline & \multicolumn{3}{|c|}{ All regions } & \multicolumn{3}{|c|}{ All regions but Oslo } \\
\hline & $(1)$ & $(2)$ & (3) & $(4)$ & $(5)$ & $(6)$ \\
\hline Norway * Post95 & $\begin{array}{c}-0.06^{* *} \\
(0.03)\end{array}$ & $\begin{array}{l}-0.03^{*} \\
(0.02)\end{array}$ & $\begin{array}{c}-0.03^{* *} \\
(0.01)\end{array}$ & $\begin{array}{c}-0.11 * * * \\
(0.02)\end{array}$ & $\begin{array}{c}-0.05^{* * *} \\
(0.01)\end{array}$ & $\begin{array}{c}-0.06^{* * *} \\
(0.01)\end{array}$ \\
\hline Norway & $\begin{array}{c}-0.10^{* * *} \\
(0.02)\end{array}$ & & & $\begin{array}{c}-0.12^{* * *} \\
(0.02)\end{array}$ & & \\
\hline Post95 & $\begin{array}{c}0.12^{* * *} \\
(0.01)\end{array}$ & $\begin{array}{c}0.08 * * * \\
(0.01)\end{array}$ & & $\begin{array}{c}0.12^{* * *} \\
(0.01)\end{array}$ & $\begin{array}{c}0.09 * * * \\
(0.01)\end{array}$ & \\
\hline $\begin{array}{l}\operatorname{Ln}(\text { Share of } \\
\text { manufacturing+1) }\end{array}$ & $-0.62^{* * *}$ & $-1.62^{* * *}$ & -0.33 & $-0.60 * * *$ & $-1.90 * * *$ & $-0.65^{*}$ \\
\hline & $(0.11)$ & $(0.45)$ & $(0.39)$ & $(0.11)$ & $(0.44)$ & $(0.37)$ \\
\hline $\operatorname{Ln}($ Share of agriculture +1$)$ & $\begin{array}{c}-2.90 * * * \\
(0.14)\end{array}$ & $\begin{array}{c}-2.38 * * * \\
(0.27)\end{array}$ & $\begin{array}{l}-0.48 \\
(0.30)\end{array}$ & $\begin{array}{c}-2.97 * * * \\
(0.12)\end{array}$ & $\begin{array}{c}-2.29 * * * \\
(0.25)\end{array}$ & $\begin{array}{l}-0.49^{*} \\
(0.28)\end{array}$ \\
\hline $\operatorname{Ln}($ Share of services +1$)$ & $\begin{array}{c}-0.65^{* * *} \\
(0.17)\end{array}$ & $\begin{array}{c}0.21 \\
(0.53)\end{array}$ & $\begin{array}{l}1.04^{* *} \\
(0.50)\end{array}$ & $\begin{array}{c}-1.02^{* * *} \\
(0.14)\end{array}$ & $\begin{array}{c}0.53 \\
(0.52)\end{array}$ & $\begin{array}{c}1.32^{* * * *} \\
(0.48)\end{array}$ \\
\hline Ln(Population density+1) & $\begin{array}{c}-0.06^{* * * *} \\
(0.02)\end{array}$ & $\begin{array}{l}8.05^{* * * *} \\
(1.15)\end{array}$ & $\begin{array}{c}5.21 * * * \\
(1.03)\end{array}$ & $\begin{array}{c}-0.04^{* *} \\
(0.02)\end{array}$ & $\begin{array}{c}5.52^{* * * *} \\
(0.77)\end{array}$ & $\begin{array}{c}2.98^{* * * *} \\
(0.66)\end{array}$ \\
\hline Ln(Investment share+1) & $\begin{array}{c}-1.01^{* * * *} \\
(0.22)\end{array}$ & $\begin{array}{c}-0.68^{* * *} \\
(0.26)\end{array}$ & $\begin{array}{l}-0.47^{*} \\
(0.25)\end{array}$ & $\begin{array}{c}-0.78^{* * *} \\
(0.20)\end{array}$ & $\begin{array}{c}-0.63^{* *} \\
(0.26)\end{array}$ & $\begin{array}{l}-0.43^{*} \\
(0.26)\end{array}$ \\
\hline Ln(Education) & $\begin{array}{l}0.20^{* *} \\
(0.10)\end{array}$ & $\begin{array}{l}-0.03 \\
(0.08)\end{array}$ & $\begin{array}{l}-0.13^{*} \\
(0.07)\end{array}$ & $\begin{array}{l}0.15^{*} \\
(0.09)\end{array}$ & $\begin{array}{l}-0.07 \\
(0.08)\end{array}$ & $\begin{array}{c}-0.15^{* *} \\
(0.07)\end{array}$ \\
\hline Constant & $\begin{array}{c}3.39 * * * \\
(0.21)\end{array}$ & $\begin{array}{c}2.92^{* * * *} \\
(0.31)\end{array}$ & $\begin{array}{c}2.66^{* * *} \\
(0.25)\end{array}$ & $\begin{array}{c}3.58^{* * * *} \\
(0.19)\end{array}$ & $\begin{array}{c}3.21 * * * \\
(0.30)\end{array}$ & $\begin{array}{c}2.92^{* * * *} \\
(0.25)\end{array}$ \\
\hline $\begin{array}{l}\text { Region FE } \\
\text { Year FE }\end{array}$ & & $\mathrm{X}$ & $\begin{array}{l}\mathrm{X} \\
\mathrm{X}\end{array}$ & & $\mathrm{X}$ & $\begin{array}{l}\mathrm{X} \\
\mathrm{X}\end{array}$ \\
\hline Observations & 464 & 464 & 464 & 448 & 448 & 448 \\
\hline R-squared & 0.81 & 0.94 & 0.95 & 0.86 & 0.95 & 0.96 \\
\hline
\end{tabular}




\section{Notes on Box A.1 to A.7. Synthetic control method estimation outcome}

To give further information that complements Figures 2 and 3, for each analysed Norwegian NUTS2 region, we report a Box. Each box contains:

- Unit weights. The name of the donor regions (Region) and their computed weight (Weight).

- Predictor balance. For each Predictor used for the construction of the counterfactual (see below for variables' definitions), we report the pre-treatment average values for the actual region and the pre-treatment average values for the synthetic region.

- $R M S P E$. The root-mean square predicted error computed in the pre-treatment period.

- Synthetic control method outcome graph. There are two series plotted in each graph; the one with a continuous line represents the actual productivity (GDP per hour worked, at 2000 constant prices) of the Norwegian region in question; the series with a dashed line plots the synthetic counterfactual results that purport to answer the following question: What would have been the productivity of the region in question if it HAD become an EU member in the year it did not (1995)?

- Placebo test graph. In each graph the black line represents the difference between the actual and the synthetic series ( $\mathrm{Y}$ axis) and over time ( $\mathrm{X}$ axis) for the Norwegian region; while the grey lines represent the same difference for each donor region after it has been exposed to the same treatment. For the construction of the counterfactual of the donor region subject to the placebo treatment, Norwegian regions and the regions from the same country of the donor region are excluded from the donor pool. We report results only for donor regions that have a comparable pre-treatment fit (i.e., we exclude those donor regions with a pre-treatment RMSPE larger than three times the pretreatment RMSPE of the Norwegian region under analysis).

Results are presented for a donor pool of 22 NUTS2 regions belonging to Austria, Finland and Sweden (which joined EU in 1995).

VARIABLES' DEFINITIONS AND DATA SOURCES: Productivity is GDP (at 2000 constant prices) per hour worked: (GDP/total employment*hours per employee per week*52 weeks); Share of manufacturing is the share of employment in energy and manufacturing on total employment; Share of agriculture is the share of employment in agriculture on total employment; Share of services is the share of employment in services (distribution, hotel \& restaurants, transport, storage and communications, financial intermediation, real estate, renting and business activities) on total employment; Population density is the ratio between population and area of the region; Investment share is the ration between total investment and GDP; all data comes from Cambridge Econometrics European Regional Database. Education are the years of schooling from Gennaioli et al. (2014). 
Box A.1. Unit weights, predictor balance, and synthetic control method outcome graph

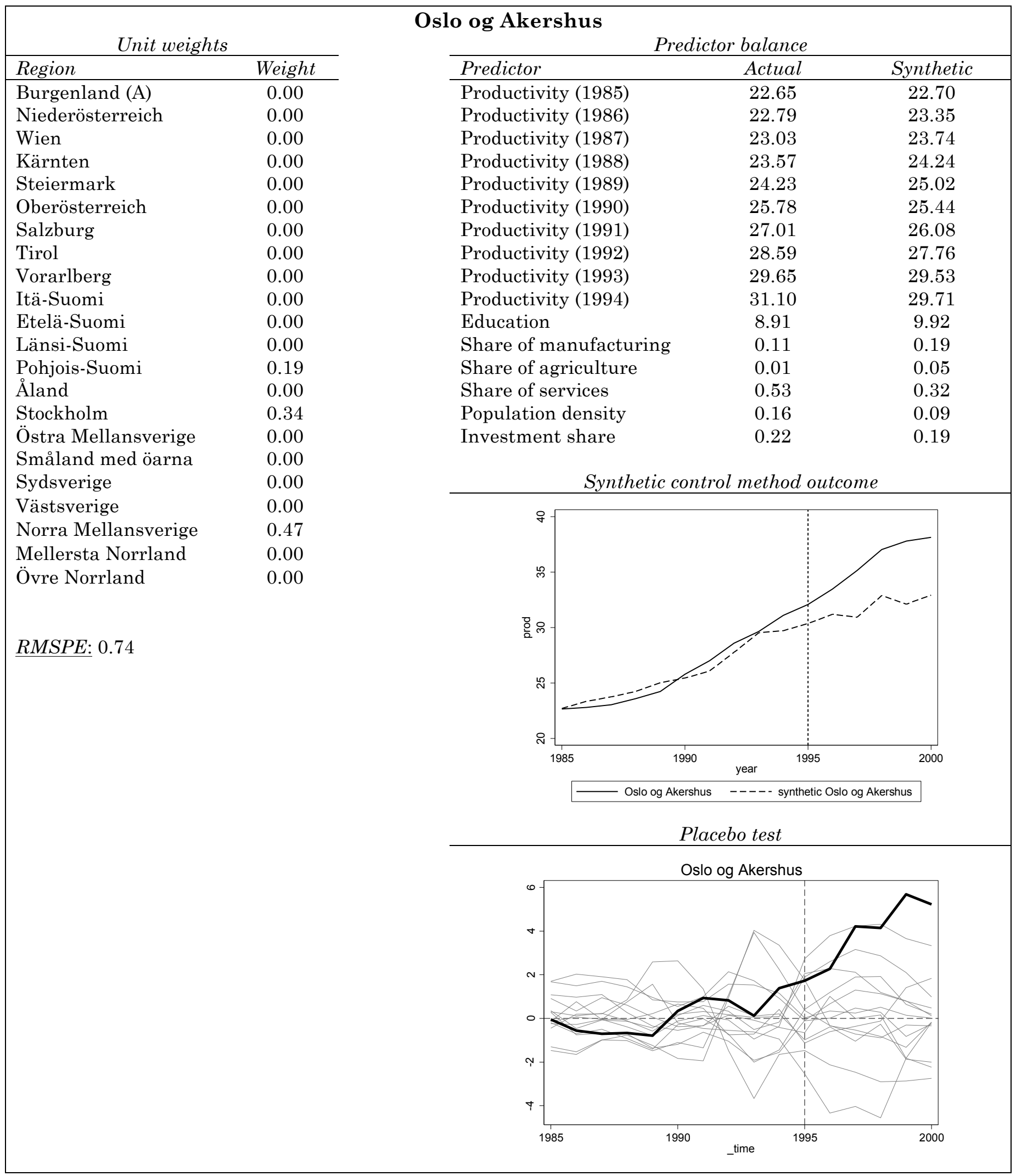


Box A.2. Unit weights, predictor balance, and synthetic control method outcome graph

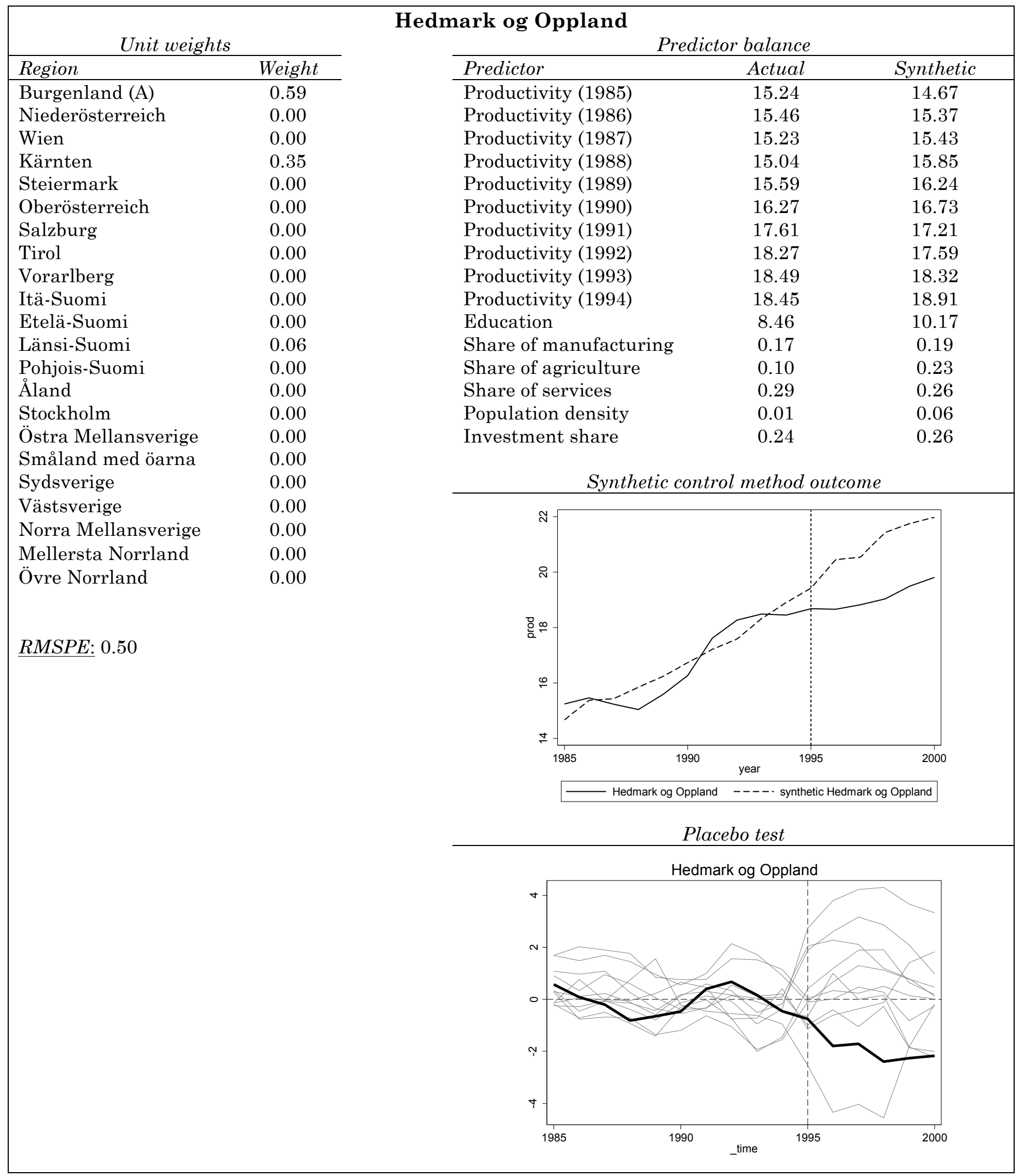


Box A.3. Unit weights, predictor balance, and synthetic control method outcome graph

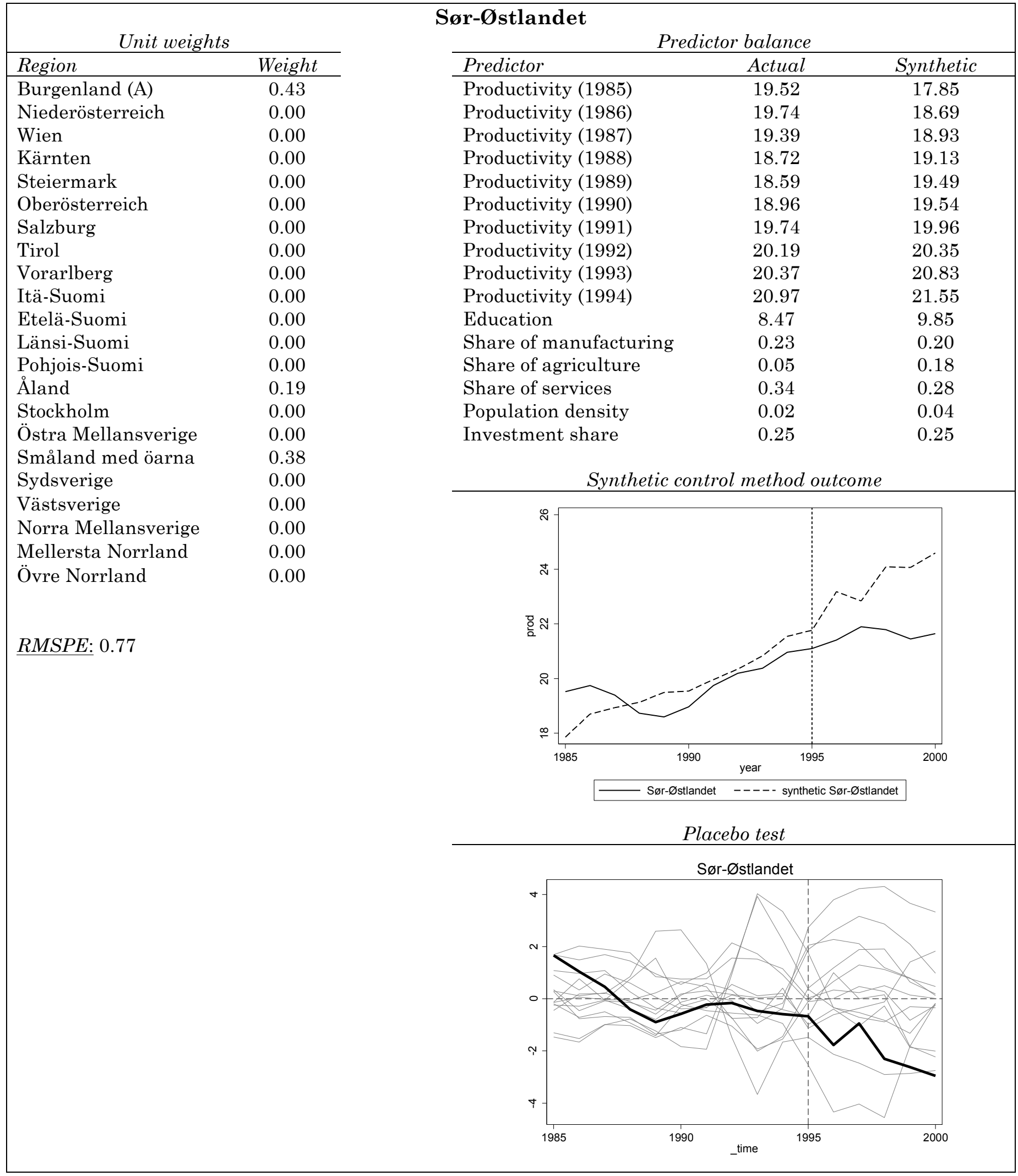


Box A.4. Unit weights, predictor balance, and synthetic control method outcome graph




Box A.5. Unit weights, predictor balance, and synthetic control method outcome graph

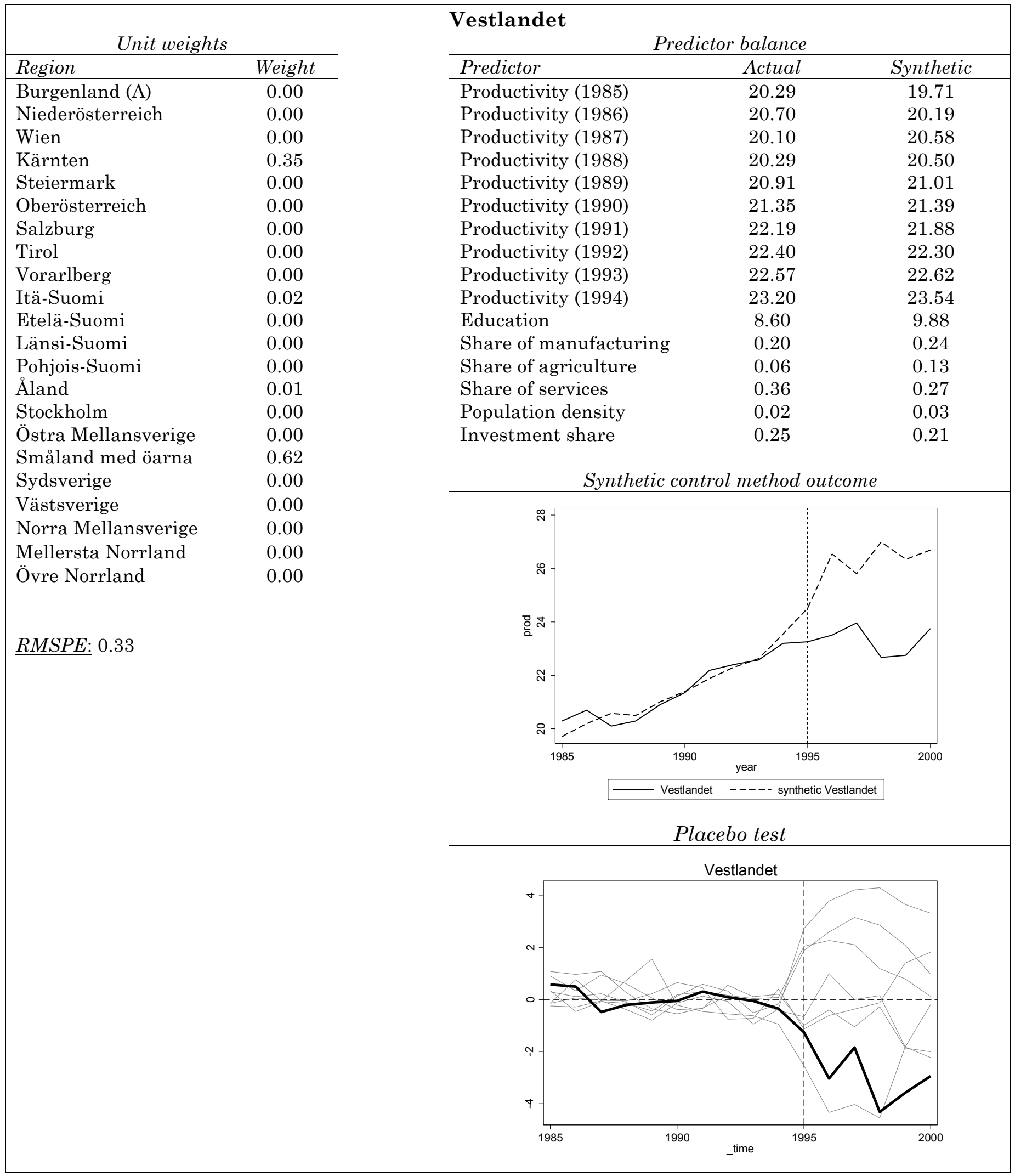


Box A.6. Unit weights, predictor balance, and synthetic control method outcome graph

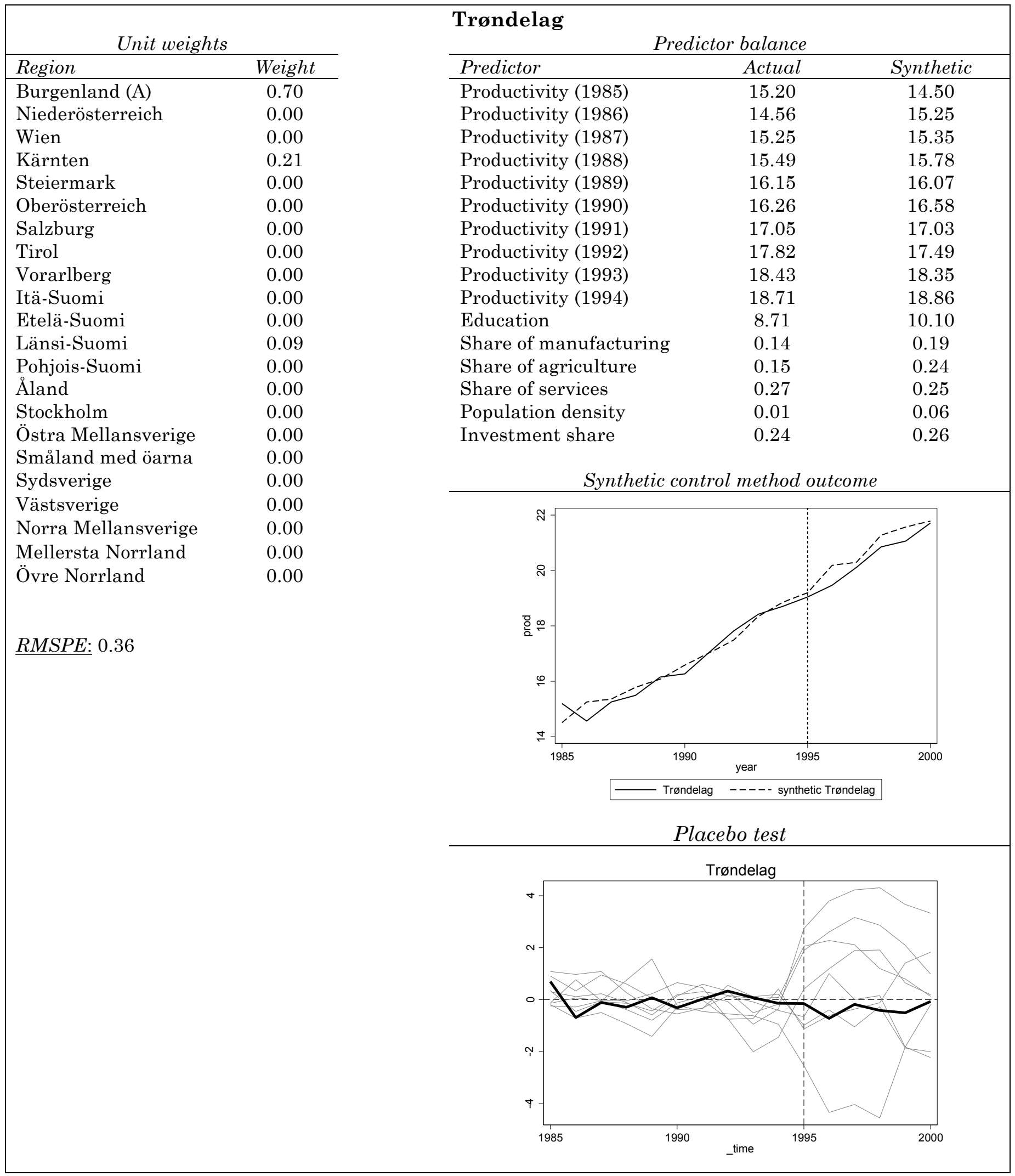


Box A.7. Unit weights, predictor balance, and synthetic control method outcome graph

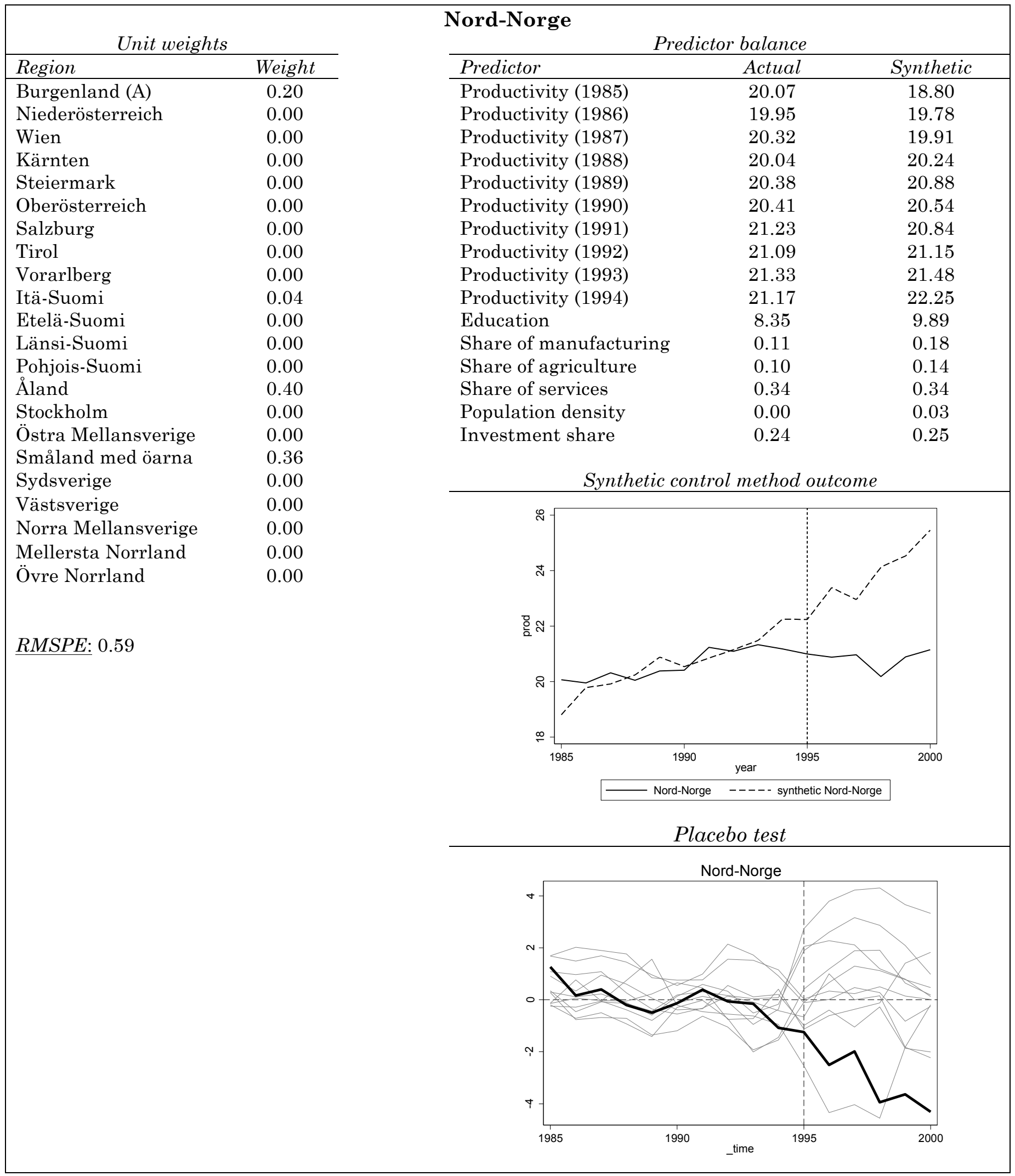


Figure A.1: Estimation from the synthetic control methods for the region of Oslo using only Wien, Helsinki, and Stockholm regions in the donor sample.

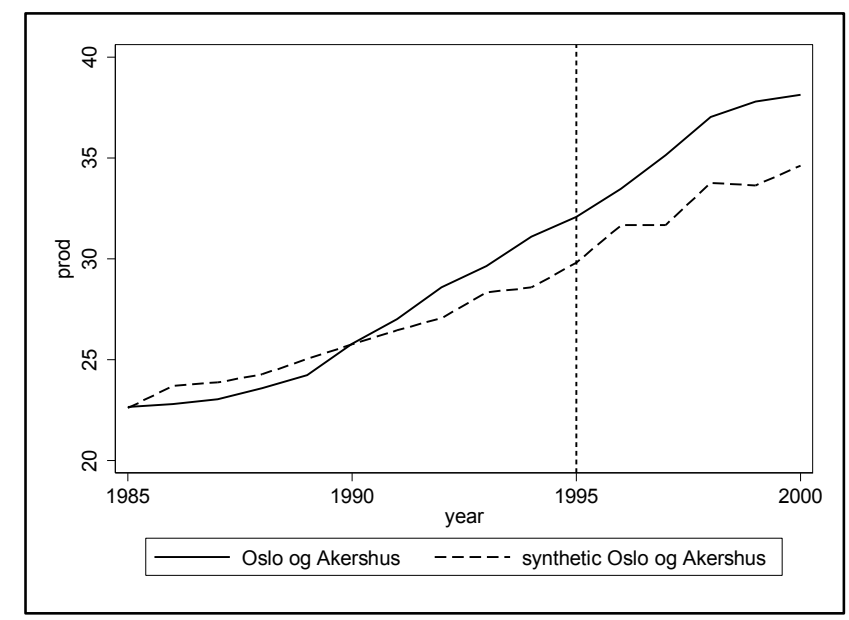

Note: Unit weights: Wien: 0.33; Etelä-Suomi: 0.20; Stockholm: 0.47. RMSPE: 1.16. Difference in productivity between actual and synthetic: Mean difference Pre-treatment: 0.28 euro; Mean difference Post-treatment: 3.08 euro. See Notes on Box A.1 to A.7 for further details and definitions. 


\section{Formal representation of the synthetic control method (SCM)}

Given the increasing use of the SCM among scholars and its application to different topics, we refer to, among others, Abadie et al. (2010 and 2014), Imbens and Wooldridge (2009), Billmeier and Nannicini (2013), and Campos et al. (2014) for a more formal discussion of the methodology. We report below a formal representation of the model. Recall that here the treatment is Norway's rejection of full EU membership.

The estimation of the treatment effect can be represented as follows:

$$
\tau_{i t}=Y_{i t}^{I}-Y_{i t}^{C}
$$

where $Y_{i t}^{I}$ is the outcome of a Norwegian region $i$ at time $t$, while $Y_{i t}^{C}$ is region $i$ 's outcome at time $t$ had it not been subjected to treatment (in this case, had it become a full-fledged member of the European Union). We observe the outcome of the Norwegian region $Y_{i t}^{I}$, but do not observe what the outcome of this region would be in the absence of treatment (i.e., the counterfactual, $Y_{i t}^{C}$, for $\left.t \geq T_{0}\right)$. Abadie et al. $(2003,2010)$ propose a method to identify and estimate the dynamic treatment effect $\left(\tau_{i t}\right)$ considering the potential outcome for the region's $i \in I$ under the following general model:

$$
\begin{aligned}
& Y_{i t}^{I}=\delta_{t}+\alpha_{i t} D_{i t}+v_{i t} \\
& Y_{i t}^{C}=\delta_{t}+v_{i t} \\
& v_{i t}=\theta_{t} Z_{i}+\lambda_{t} \omega_{i}+\varepsilon_{i t}
\end{aligned}
$$

where $Z_{i}$ is a vector of independent variables at regional level (either time-invariant or timevariant); $\theta_{t}$ is a vector of parameters; $\lambda_{t}$ is an unknown common factor; $\omega_{i}$ is a region specific unobservable term; $\varepsilon_{i t}$ is a zero-mean transitory shock, and $\alpha_{i t} D_{i t}=\tau_{i t}$, where $D_{i t}$ is dummy variable which takes value 1 when the region $i \in I$ is in a country exposed to the treatment, and zero otherwise.

Suppose we observe the outcome $Y_{i t}$ and a set of determinants $Z_{i t}$ of the outcome for $N+1$ regions, where $i=1$ is the treated region and $i=2, \ldots, N+1$ are the (untreated) donor regions, for each period $t \in[1, T]$, with the intervention on region $i=1$ beginning at time $T_{0} \in(1, T)$. In order to construct a counterfactual, i.e. an estimation of the outcome variable for the treated region had the region not affected by the treatment as the donor regions, a weighted average of $Y_{i t}$ (with $i=2, \ldots, N+1$, and $t<T_{0}$ ) is estimated to approximate $Y_{1 t}$ (for $\left.t<T_{0}\right)$, taking into account the covariates $Z$. The set of weights is $W=\left(w_{2}, \ldots, w_{n+1}\right)$, with $w_{i} \geq 0$ (for $i=2, \ldots, N+1$ ) and $\sum_{i=2}^{N+1} w_{i}=1$, thus in the pre-treatment:

and

$$
\sum_{i=2}^{N+1} w_{i} Y_{i t}=Y_{1 t}
$$

$$
\sum_{i=2}^{N+1} w_{i} Z_{i}=Z_{1}
$$

For the choice of the optimal set of weights $W^{*}$, consider, in matrix notation, $X_{1}$ the $(k \times 1)$ vector of the treated region characteristics in the pre-treatment period; $X_{C}$ the $(k \times N)$ vector of the same characteristics for the untreated donor regions; and, $V$ a $(k \times k)$ symmetric and positive semi definite matrix, which measures the relative importance of the characteristics included in $X$. The optimal vector of weights $W^{*}$ solves the following minimization problem: 


$$
\begin{aligned}
& \min \left(X_{1}-X_{C} W\right)^{\prime} V\left(X_{1}-X_{C} W\right) \\
& \text { s.t. } w_{i} \geq 0(\text { for } i=2, \ldots, N+1) \text { and } \sum_{i=2}^{N+1} w_{i}=1
\end{aligned}
$$

That is, $W^{*}$ is selected to minimize the pre-treatment distance between the vector of the treated region characteristics and the vector of the potential synthetic control characteristics. $W^{*}$ is chosen to minimize the mean squared error of pre-treatment outcomes. ${ }^{12}$

The synthetic counterfactual is constructed using the optimal weight $W^{*}$ so that $\sum_{i=2}^{N+1} w_{i}^{*} Y_{i t}$ (with $t \geq T_{0}$ ) is an approximate estimation of $Y_{1 t}^{C}$. The treatment effects are estimated as:

$$
\hat{\tau}_{i t}=Y_{1 t}-\sum_{i=2}^{N+1} w_{i}^{*} Y_{i t} \text { for all } t \geq T_{0}
$$

The path of the weighted average of (untreated) donor regions (i.e. the synthetic control) hence matches or mimics the path of the Norwegian region, had it not been affected by the treatment. The accuracy of the estimation depends on the pre-treatment distance of the synthetic control with respect to the treated region. All else equal, a longer pre-treatment period allows for a more accurate synthetic control.

The synthetic counterfactuals method entail two identification assumptions: (1) the choice of the pre-treatment characteristics should include variables that can approximate the path of the treated region, but should not include variables that anticipate the effects of the intervention; and (2) the regions used to obtain the synthetic control (those in the "donor pool") must not have been affected by the treatment.

In our framework, the first assumption implies that the chosen covariates included in $\mathrm{Z}$ do not reflect agents' expectations that Norway would not have finally joined the EU. This is not the case, as Norway rejected the full EU membership with a referendum at the end of 1994 (thus, only one month before the beginning of our treatment period) and until then the situation was uncertain.

Recalling that our goal is to assess the effect of the full integration compared to partial integration, the second assumption requires that donor regions we selected to generate the synthetic control group for Norwegian region must have joined the EU by the time Norway decided to reject the "full-fledged EU membership".

${ }_{12}$ In this paper we use the distance metric available in the STATA econometric software (the relevant command is synth). See Abadie et al. (2010) for further details. 